\title{
A Biochemical-Biophysical Study of Hemoglobins from Woolly Mammoth, Asian Elephant, and Humans
}

\author{
Yue Yuan, ${ }^{\dagger}$ Tong-Jian Shen, ${ }^{\dagger}$ Priyamvada Gupta, ${ }^{\dagger}$ Nancy T. Ho, ${ }^{\dagger}$ Virgil Simplaceanu, ${ }^{\dagger}$ \\ Tsuey Chyi S. Tam, ${ }^{\dagger}$ Michael Hofreiter, ${ }^{\ddagger}$ Alan Cooper, ${ }^{\S}$ Kevin L. Campbell, ${ }^{\perp}$ and Chien Ho ${ }^{*}{ }^{\dagger}$ \\ ${ }^{\dagger}$ Department of Biological Sciences, Carnegie Mellon University, Pittsburgh, Pennsylvania 15213, United States \\ ${ }^{\ddagger}$ Department of Biology, University of York, York, YO10 5YW, United Kingdom

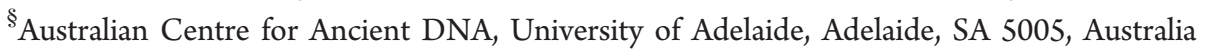 \\ ${ }^{\perp}$ Department of Biological Sciences, University of Manitoba, Winnipeg, Manitoba R3T 2N2, Canada
}

Supporting Information

\begin{abstract}
This study is aimed at investigating the molecular basis of environmental adaptation of woolly mammoth hemoglobin $(\mathrm{Hb})$ to the harsh thermal conditions of the Pleistocene ice ages. To this end, we have carried out a comparative biochemical-biophysical characterization of the structural and functional properties of recombinant hemoglobins $(\mathrm{rHb})$ from woolly mammoth ( $\mathrm{rHb}$ $\mathrm{WM}$ ) and Asian elephant ( $\mathrm{rHb} \mathrm{AE})$ in relation to human hemoglobins $\mathrm{Hb} \mathrm{A}$ and $\mathrm{Hb} \mathrm{A}_{2}$ (a minor component of human blood). We have obtained oxygen equilibrium curves and calculated $\mathrm{O}_{2}$ affinities, Bohr effects, and the apparent heat of oxygenation $(\Delta H)$ in the presence and absence of allosteric effectors [inorganic phosphate and inositol hexaphosphate (IHP)]. Here, we show that

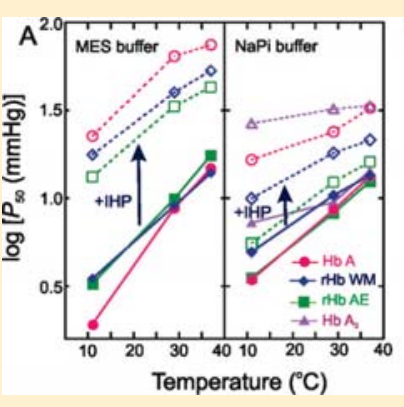
B $\mathrm{rHb}$ Woolly Mammoth

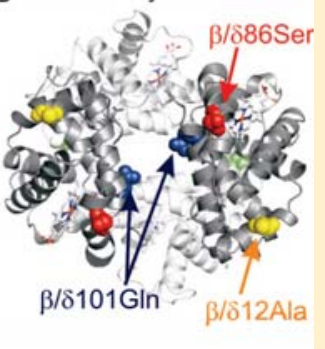
the four Hbs exhibit distinct structural properties and respond differently to allosteric effectors. In addition, the apparent heat of oxygenation $(\Delta H)$ for $\mathrm{rHb} \mathrm{WM}$ is less negative than that of $\mathrm{rHb} \mathrm{AE}$, especially in phosphate buffer and the presence of IHP, suggesting that the oxygen affinity of mammoth blood was also less sensitive to temperature change. Finally, ${ }^{1} \mathrm{H}$ NMR spectroscopy data indicates that both $\alpha_{1}(\beta / \delta)_{1}$ and $\alpha_{1}(\beta / \delta)_{2}$ interfaces in $\mathrm{rHb} \mathrm{WM}$ and $\mathrm{rHb} \mathrm{AE}$ are perturbed, whereas only the $\alpha_{1} \delta_{1}$ interface in $\mathrm{Hb} \mathrm{A}_{2}$ is perturbed compared to that in $\mathrm{Hb} \mathrm{A}$. The distinct structural and functional features of $\mathrm{rHb} \mathrm{WM}$ presumably facilitated woolly mammoth survival in the Arctic environment.
\end{abstract}

$\mathrm{H}$ uman normal adult hemoglobin ( $\mathrm{Hb} \mathrm{A}$ ) is a heterotetramer consisting of two $\alpha$-subunits and two $\beta$-subunits. ${ }^{1}$ Within the bloodstream, this respiratory protein switches cyclically between high and low $\mathrm{O}_{2}$-affinity states to control the delicate balance between the uptake of $\mathrm{O}_{2}$ at the alveoli and its optimal unloading at the tissues. However, because $\mathrm{Hb}$ oxygenation is exothermic, this balance is disrupted by changes in temperature such that $\mathrm{O}_{2}$ affinity decreases sharply with increasing temperature and increases with decreasing temperature. ${ }^{1}$ Although this trait is often considered "adaptive" for enhancing $\mathrm{O}_{2}$ offloading at warm (exercising) muscles, it may pose considerable challenges for $\mathrm{O}_{2}$ delivery to cool extremities and peripheral tissues of heterothermic mammals and hence is often countered..$^{2}$ However, the molecular mechanisms by which the thermal sensitivity of the $\mathrm{O}_{2}$ affinity of $\mathrm{Hb}$, which is dictated by the overall enthalpy of oxygenation $(\Delta H)$, has been lowered through evolution within the various cold-adapted mammalian lineages are poorly understood. ${ }^{3-5}$ Elephantids are a particularly good model system to investigate the effects of temperature on $\mathrm{Hb}$ structure-function relationships as they possess both warmand cold-adapted members. Specifically, the group evolved in warm subtemperate climates, where extant Asian and African lineages are still found, with the ancestors of the extinct woolly mammoth (Mammuthus primigenius) abruptly invading highlatitude environments of Eurasia near the start of the Pleistocene ice ages some 1.2-2.0 million years ago. ${ }^{6}$ Consistent with this environmental diaspora, the functional properties of woolly mammoth $\mathrm{Hb}$ were found to differ substantially from those of Asian elephant $\mathrm{Hb}$, with the most notable change being a significant reduction in the overall $\Delta H$ of the mammoth protein in the presence of naturally occurring allosteric effector molecules. ${ }^{6}$ Interestingly, this functional shift comes about despite the fact that the primary sequences of Asian elephant $\mathrm{Hb}$ differ from those of the mammoth at only one position in the $\alpha$-globin chain (K5N) and at three positions (T12A, A86S, and E101Q) in the $\beta$-type globin chain, respectively (Table 1$){ }^{6}$ Of these latter residues, $\beta / \delta 12 \mathrm{Ala}$ of the mammoth protein is near the 2,3-bisphosphoglycerate (BPG) binding cleft, $\beta / \delta 86$ Ser is in the heme pocket, and $\beta / \delta 101 \mathrm{Gln}$ is located between 99Asp and 102Asn of the same chain in the intersubunit $\alpha_{1}(\beta / \delta)_{2}$ interface, which are all critical to the function of $\mathrm{Hb}^{1}{ }^{1}$ Indeed, naturally occurring human mutations at $\beta 101$ have illustrated that changes

Received: May 19, 2011

Revised: July 14, 2011

Published: August 2, 2011 
Table 1. Amino Acid Residue Differences among the $\alpha$ - and $\beta$-Type Globin Chains of Humans Hb A and $\mathrm{A}_{2},{ }^{9}$ Asian Elephant (rHb AE), and Woolly Mammoth $(\mathrm{rHb} \mathrm{WM})^{a}$

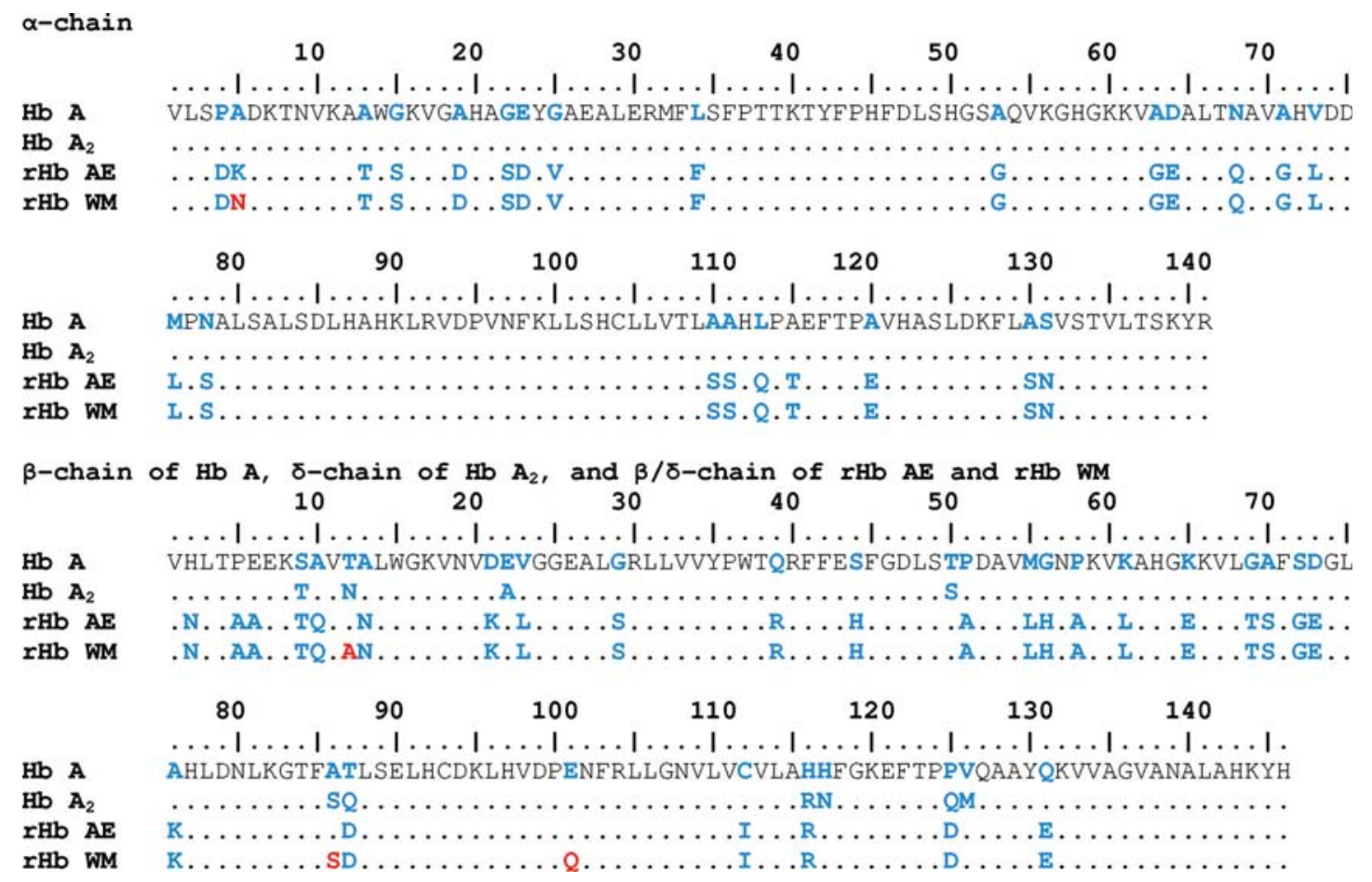

${ }^{a}$ Differences from the $\mathrm{Hb}$ A sequence are colored in blue. Amino acid residue in $\mathrm{rHb} \mathrm{WM}$ which differs with that in $\mathrm{rHb} \mathrm{AE}$ is colored in red.

at this residue position alter both the intrinsic and allosteric properties of the protein, though the mechanism by which this residue exerts these effects is still unclear. ${ }^{7}$

The $\mathrm{Hb}$ of elephantids is unusual in that the $\beta$-type subunit is encoded by a chimeric $\beta / \delta$-fusion gene $(H B B / D)$ that arose via an unequal crossing over event long before the radiation of this group. ${ }^{6,8}$ Consequently, the $\mathrm{N}$ - and $\mathrm{C}$ - terminal halves of the hybrid elephantid polypeptide are orthologous to the " $\beta$ " and " $\delta$ " globin chains of other mammals, respectively. Thus, it would be interesting to probe the structural significance of this evolutionary change, as the physiochemical properties of human $\mathrm{Hb} \mathrm{A}$ and $\mathrm{Hb} \mathrm{A}_{2}$ (a minor $\alpha_{2} \delta_{2}$ tetramer component of human blood)-which differ at only 10 residue positions (Table 1$)^{9}$ - show important differences in regards to antisickling properties and thermal stability. ${ }^{10}$

The primary objective of this study is to evaluate and compare the biochemical factors that alter the temperature dependence of $\mathrm{O}_{2}$ binding to Asian elephant and mammoth $\mathrm{Hb}$, with special reference to human $\mathrm{Hbs} A$ and $\mathrm{A}_{2}$. Additionally, we aim to provide new insights into the structural mechanisms that affect $\mathrm{Hb}$ function, thereby aiding the design of a new generation of medically relevant $\mathrm{Hb}$-based oxygen carriers (blood substitutes) for use, e.g., during certain hypothermia-dependent cardiac and brain surgery applications. ${ }^{11}$ To this end, we obtained the ${ }^{1} \mathrm{H}$ NMR spectra of the four $\mathrm{Hbs}$ and measured their oxygen affinity, sensitivity to various allosteric effectors, and cooperativity at three different temperatures $\left(37,29\right.$, and $\left.11^{\circ} \mathrm{C}\right)$ and over a range of $\mathrm{pH}$ ( $\mathrm{pH} 8.5$ to 5.5$)$.

\section{MATERIALS AND METHODS}

Materials. $\mathrm{Hb} \mathrm{A}$ and $\mathrm{Hb} \mathrm{A}_{2}$ were isolated and purified from human normal blood samples obtained from the local blood bank using the procedures routine in our laboratory. ${ }^{12,13}$ Chemicals and restriction enzymes were purchased from major suppliers, such as Fisher, Sigma, Bio-Rad, Boehringer Mannheim, New England BioLabs, Pharmacia, Promega, and United States Biochemicals, Inc., and were used without further purification.

Construction of Expression Plasmids. The plasmid ( $\mathrm{pHE} 27 \mathrm{E})$ that expresses recombinant $\mathrm{Hb} \mathrm{AE}$ was constructed by replacing the human $\alpha$ - and $\beta$-globin genes in $\mathrm{Hb}$ expression plasmid $\mathrm{pHE}^{12}$ with Asian elephant $\alpha$-like and $\beta / \delta$-like cDNAs. The plasmid (pHE27M) for expressing rHb WM was constructed by introducing the mammoth-specific residue mutations $(\alpha \mathrm{K} 5 \mathrm{~N}, \beta / \delta \mathrm{T} 12 \mathrm{~A}, \beta / \delta \mathrm{A} 86 \mathrm{~S}$, and $\beta / \delta \mathrm{E} 101 \mathrm{Q})$ into pHE27E using site-directed mutagenesis. The desired mutations were confirmed by DNA sequencing. For additional details, see ref 6.

Growth and Purification of rHbs. Plasmids for $\mathrm{rHb} \mathrm{AE}$ (pHE27E) and $\mathrm{rHb} \mathrm{WM}(\mathrm{pHE} 27 \mathrm{M})$ were transformed into E. coli strain JM109, and the cells were grown in a minimal medium in a $20 \mathrm{~L}$ fermentor (B. Braun Biotech International, Model Biostat C) at $32{ }^{\circ} \mathrm{C}$ until the optical density reached $\sim 10$ at $600 \mathrm{~nm}$. Isopropyl $\beta$-D-thiogalactopyranoside (IPTG) was then added at a concentration of $24 \mathrm{mg} / \mathrm{L}$ to induce the expression of the rHbs. After the addition of hemin $(25 \mathrm{mg} / \mathrm{L})$, growth was continued for at least another $4 \mathrm{~h}$. Harvesting was accomplished through centrifugation. Cell paste was stored at $-80{ }^{\circ} \mathrm{C}$ until it was needed. The purification of $\mathrm{rHb}$ followed 


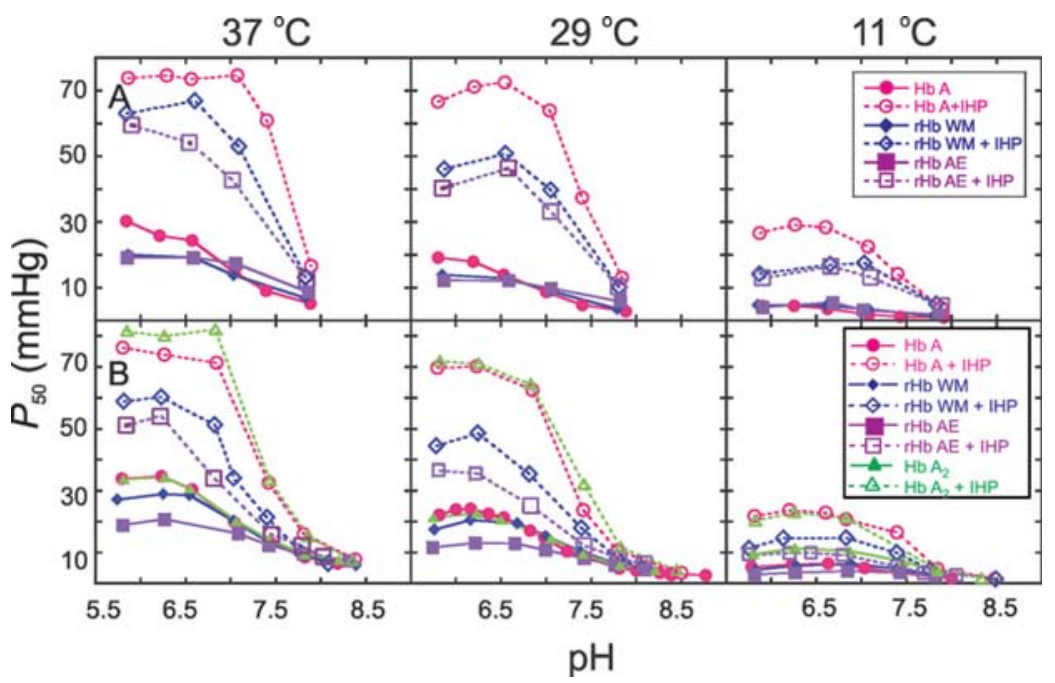

Figure 1. $\mathrm{pH}$ dependence of the oxygen-binding properties $\left(P_{50}\right.$, in $\left.\mathrm{mmHg}\right)$ of $\mathrm{Hb} \mathrm{A}(\mathrm{O}$, red $), \mathrm{Hb} \mathrm{A}_{2}(\triangle$, green), $\mathrm{rHb} \mathrm{WM}(\diamond$, blue), and $\mathrm{rHb} \mathrm{AE}$ ( $\square$, magenta) in (A) 0.1 M MES buffer and in (B) $0.1 \mathrm{M}$ sodium phosphate buffer in the absence (filled) and presence (open) of IHP and at 37, 29, and $11{ }^{\circ} \mathrm{C}$.

the previous procedure. ${ }^{12,14}$ The purity of the rHbs was then checked with an electrospray ionization mass spectrometer and Edman degradation as described previously. ${ }^{12,14}$ All rHbs used in this study had the correct molecular weights and contained less than 5\% methionine at the amino termini.

Oxygen-Binding Properties of Hbs. Oxygen-equilibrium curves for these four Hbs were measured in both $0.1 \mathrm{M} 2-(\mathrm{N}$ morpholino)ethanesulfonic acid (MES) and $0.1 \mathrm{M}$ sodium phosphate buffers at 11,29 , and $37^{\circ} \mathrm{C}$ with a Hemox Analyzer. Experiments were conducted in the presence and absence of three-time molar concentrations of inositol hexaphosphate (IHP), in the $\mathrm{pH}$ range 5.5 to 8.5 . The sample concentration of Hbs used 100-120 $\mu \mathrm{M}$ (in terms of heme) was selected to avoid tetramer-dimer dissociation. Each sample was checked before and after each measurement for methemoglobin (met-Hb) in a spectrophotometer. Any sample with greater than $5 \%$ met- $\mathrm{Hb}$ was discarded. The partial pressure of $\mathrm{O}_{2}$ at $50 \% \mathrm{Hb}$ saturation $\left(P_{50}\right)$, a measure of oxygen affinity, and the Hill coefficient $\left(n_{50}\right)$, a measure of the cooperativity of the oxygenation process, were calculated for each oxygenequilibrium curve. The $P_{50}$ values $(\mathrm{mmHg})$ have an accuracy of $\pm 5 \%$, and the $n_{50}$ values have an accuracy of $\pm 10 \%$.

${ }^{1} \mathrm{H}$ NMR Spectroscopy. To detect changes in the tertiary or quaternary structure of the two elephantid Hbs, ${ }^{1} \mathrm{H}$ NMR spectra were obtained on Bruker Avance DRX-300 (results not shown) and DRX-600 NMR spectrometers. Samples consisted of aqueous solutions of $\mathrm{Hb}$ at a concentration of $5 \%(3.1 \mathrm{mM}$ in terms of heme) in $0.1 \mathrm{M}$ sodium phosphate buffer at $\mathrm{pH} 7.0$ in $95 \%$ water and $5 \%$ deuterium oxide $\left(\mathrm{D}_{2} \mathrm{O}\right)$ and were assessed at 11,29 , and $37{ }^{\circ} \mathrm{C}$. A jump-and-return pulse sequence was used to suppress the water signal. ${ }^{1} \mathrm{H}$ chemical shifts were indirectly referenced to the methyl proton resonance of the sodium salt of 2,2-dimethyl-2-silapentane-5sulfonate (DSS) through use of the internal reference of the water signal at $4.76 \mathrm{ppm}$ downfield of DSS at $29{ }^{\circ} \mathrm{C}$.

\section{RESULTS}

Oxygen-Binding Properties in MES and Phosphate Buffers. The functional properties of the four $\mathrm{Hbs}$ were studied by measuring their oxygen-binding affinities as a function of buffer, $\mathrm{pH}$, and temperature in the presence or absence of IHP (Figure 1). Each of the Hbs studied exhibits distinct functional properties, with $P_{50}$ values varying widely between $\mathrm{Hbs}$. Notably, $\mathrm{rHb} \mathrm{WM}$ has a lower $\mathrm{O}_{2}$ affinity (higher $P_{50}$ value) than that of $\mathrm{rHb} \mathrm{AE}$ under the various experimental conditions (Figure 1). The $P_{50}$ values of $\mathrm{Hb} \mathrm{A}$ and $\mathrm{Hb} \mathrm{A}_{2}$ are very similar and always higher than those of $\mathrm{rHb} \mathrm{WM}$ and $\mathrm{rHb}$ AE. The $P_{50}$ values are also affected remarkably by buffer condition. For instance, in MES buffer and in the absence of IHP ("stripped" condition), the differences of the $P_{50}$ values between $\mathrm{rHb} \mathrm{WM}$ and $\mathrm{rHb} \mathrm{AE}$ are very small (Figure 1A) but become significant in phosphate buffer (Figure 1B) due to their different response to phosphate ion. Similarly, the addition of IHP to $\mathrm{Hbs}$ significantly decreases the $\mathrm{O}_{2}$ affinities in both MES buffer and phosphate buffer, but the relative IHP effect is much stronger in MES buffer. Thus, in the presence of IHP, the $\mathrm{O}_{2}$ affinities of these $\mathrm{Hbs}$ are always lower in MES buffer than in phosphate buffer (Figure 2). The effects of the buffer and IHP on the $\mathrm{O}_{2}$ affinities are also illustrated by the dramatic shift of the oxygen-binding curves. For example, at $\mathrm{pH} 7$ and $37^{\circ} \mathrm{C}$, in the absence of IHP, the $\mathrm{O}_{2}$-binding curves for these $\mathrm{Hbs}$ are very close in MES buffer (Figure 3A) but become scattered in phosphate buffer (Figure 3B). Upon the addition of IHP, all of the binding curves are shifted to the right in both buffers. Finally, it is noted that the addition of IHP affects the $\mathrm{O}_{2}$ affinities of $\mathrm{Hb} \mathrm{A}$ and $\mathrm{Hb} \mathrm{A}_{2}$ the most, followed by $\mathrm{rHb} \mathrm{WM}$, whereas $\mathrm{rHb} \mathrm{AE}$ is affected the least by IHP (Figure 3 ).

The cooperativity of the oxygenation process for all $\mathrm{Hbs}$ can be assessed by the Hill coefficient, $n_{50}$. The $n_{50}$ values for Hbs under various experimental conditions are taken as the slope of the Hill plots at $50 \%$ saturation and are summarized in the Supporting Information Table 1S. The $n_{50}$ values change significantly in the presence of IHP but are only slightly affected by buffer, temperature, and $\mathrm{pH}$. For example, as shown in Figure 4, the $n_{50}$ values for both $\mathrm{Hb} \mathrm{A}$ and $\mathrm{Hb} \mathrm{A}_{2}$ are maintained around the expected value of $2.8-3.0$ in the range of $\mathrm{pH} 5.8-8.4$ in $0.1 \mathrm{M}$ phosphate buffer at $29{ }^{\circ} \mathrm{C}$, while $n_{50}$ values for $\mathrm{rHb} \mathrm{WM}$ and $\mathrm{rHb} \mathrm{AE}$ are found to have lower values $(2.0-2.5)$ under the same experimental conditions. Upon the addition of IHP, a broader spectrum of differences in the $n_{50}$ 


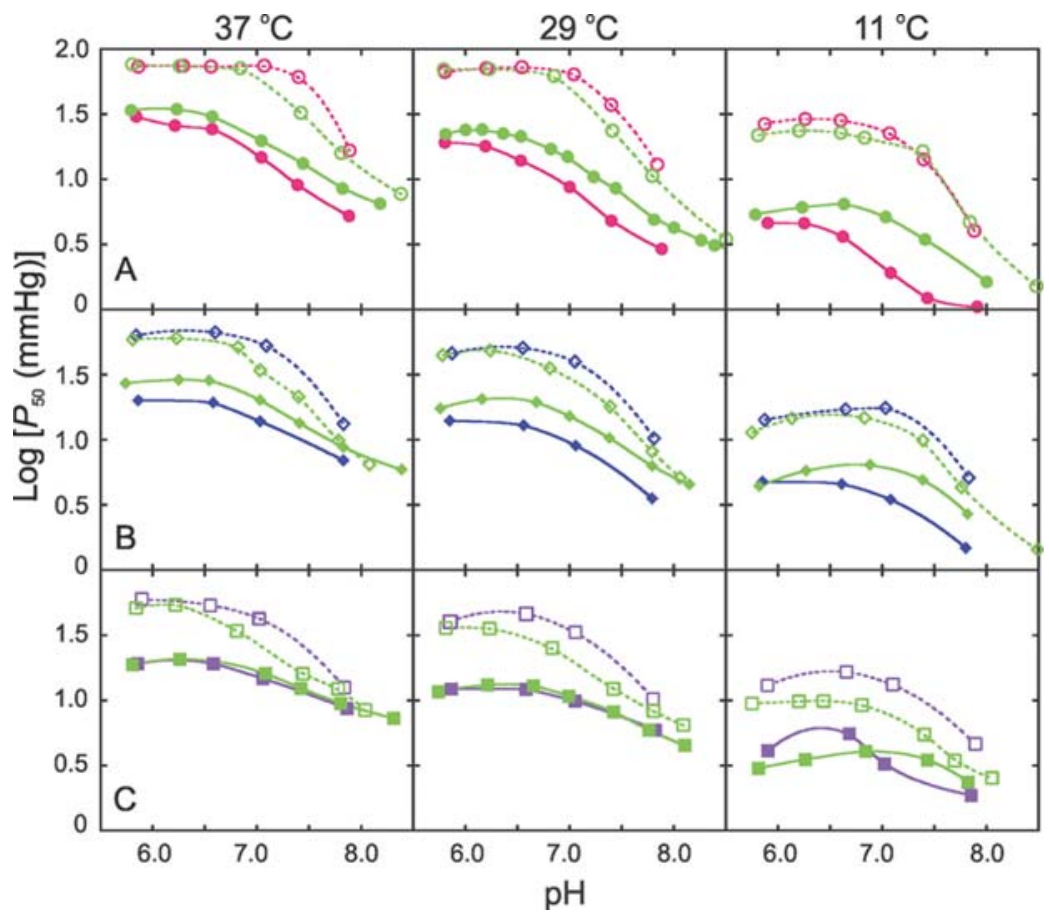

Figure 2. Comparison of $\mathrm{pH}$ dependence of the oxygen-binding properties $\left[\log P_{50}(\mathrm{mmHg})\right]$ for $(\mathrm{A}) \mathrm{Hb} \mathrm{A}(\mathrm{O}, \mathrm{red}),(\mathrm{B}) \mathrm{rHb} \mathrm{WM}(\diamond, \mathrm{blue})$, and (C) $\mathrm{rHb} \mathrm{AE} \mathrm{( \square ,} \mathrm{magenta)} \mathrm{measured} \mathrm{in} \mathrm{0.1} \mathrm{M} \mathrm{MES} \mathrm{buffer} \mathrm{and} \mathrm{in} \mathrm{the} \mathrm{absence} \mathrm{(filled)} \mathrm{and} \mathrm{presence} \mathrm{(open)} \mathrm{of} \mathrm{IHP} \mathrm{and} \mathrm{at} \mathrm{11,} \mathrm{29,} \mathrm{and} 37{ }^{\circ} \mathrm{C}$, respectively. Measurements conducted for the three $\mathrm{Hbs}$ in $0.1 \mathrm{M}$ sodium phosphate buffer (green) are also presented.

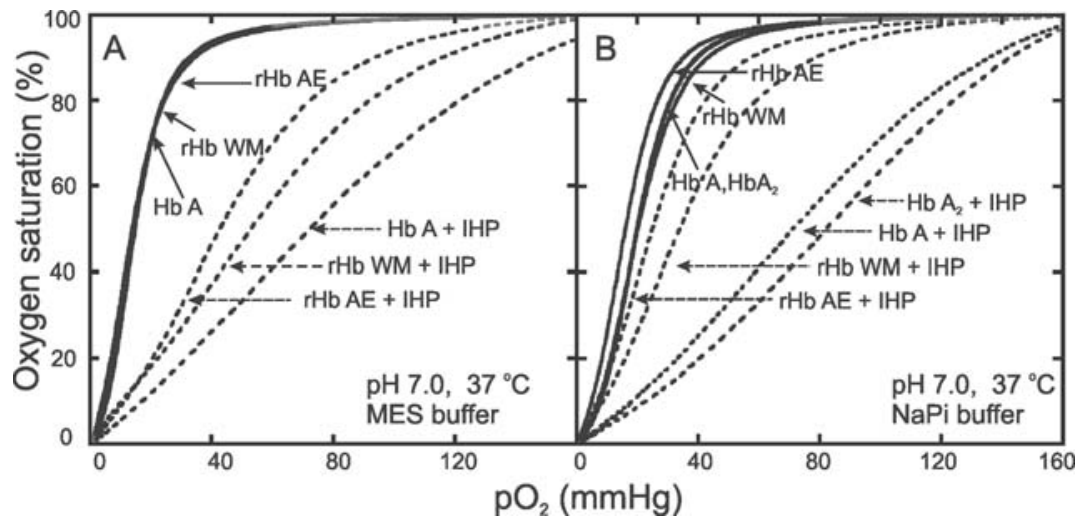

Figure 3. Percent of $\mathrm{O}_{2}$ saturation of $\mathrm{Hb} \mathrm{A}, \mathrm{Hb} \mathrm{A} 2$, $\mathrm{rHb}$ Asian elephant (AE), and $\mathrm{rHb}$ woolly mammoth (WM) as a function of $\mathrm{O}_{2}$ partial pressure at $\mathrm{pH} 7.0$ and $37^{\circ} \mathrm{C}$ in (A) $0.1 \mathrm{M}$ MES buffer and in (B) $0.1 \mathrm{M}$ sodium phosphate (NaPi) buffer in the absence (solid lines) and presence (dashed lines) of IHP.

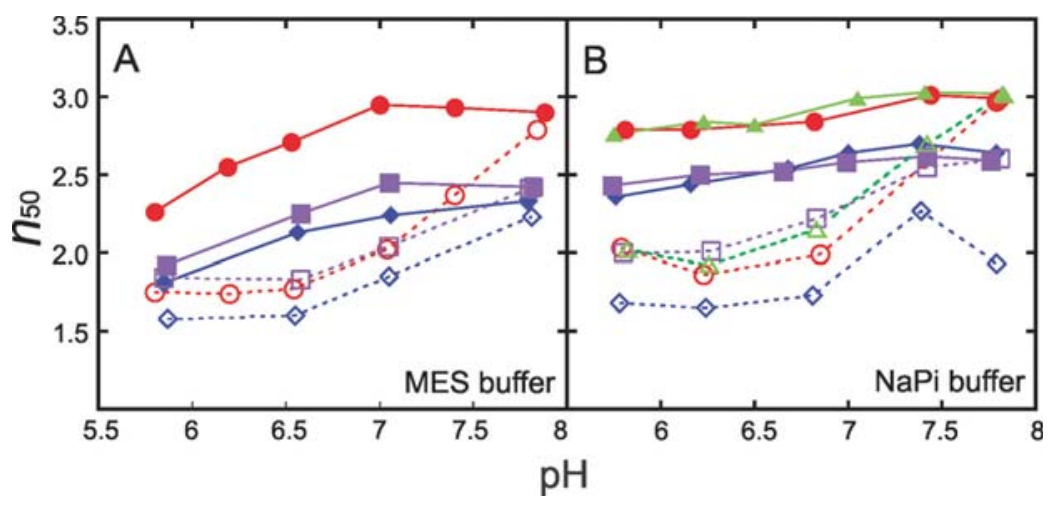

Figure 4. Hill coefficient $\left(n_{50}\right)$ of $\mathrm{Hb} \mathrm{A}\left(\bigcirc\right.$, red), $\mathrm{Hb} \mathrm{A}_{2}\left(\triangle\right.$, green), $\mathrm{rHb}$ WM $\left(\diamond\right.$, blue), and $\mathrm{rHb} \mathrm{AE}\left(\square\right.$, magenta) as a function of $\mathrm{pH}$ at $29{ }^{\circ} \mathrm{C}$ in (A) 0.1 M MES buffer and in (B) 0.1 M sodium phosphate (NaPi) buffer in the absence (filled) and presence (open) of IHP. 
values is observed with $n_{50}$ being generally reduced at lower $\mathrm{pH}$ values and close to $n_{50}$ values measured in the absence of IHP at higher $\mathrm{pHs}$. Of note, the $n_{50}$ values of $\mathrm{rHb} \mathrm{WM}$ are generally lower than those of the other $\mathrm{Hbs}$ under all experimental conditions (Figure 4).

The usual $\mathrm{Hb}$ concentration used for our $\mathrm{O}_{2}$-binding measurements is $100-120 \mu \mathrm{M}$ (in terms of heme). In order to investigate if $\mathrm{rHb} \mathrm{WM}$ and $\mathrm{rHb} \mathrm{AE}$ exhibit unusual tetramerdimer dissociation, we have also carried out a concentrationdependent study of the $\mathrm{O}_{2}$-binding measurements of these two $\mathrm{Hbs}$ together with $\mathrm{Hb} \mathrm{A}$ over a $\mathrm{Hb}$ concentration range of $25-100 \mu \mathrm{M}$ in $0.1 \mathrm{M}$ sodium phosphate buffer at $\mathrm{pH} 7.4$ and $37{ }^{\circ} \mathrm{C}$. No observable differences in both $P_{50}$ and $n_{50}$ values among these concentrations were found, indicating that there is no significant tetramer-dimer dissociation over the range of experimental conditions studied (see Supporting Information Table 2S).

Bohr Effect. The $\mathrm{pH}$ dependence of the oxygen affinity of $\mathrm{Hbs}$ is measured over a range of $\mathrm{pH} 8.5$ to 5.5 , and a significant difference is found in the amplitude of the alkaline Bohr effect $\left(\Delta \log P_{50} / \Delta \mathrm{pH}\right.$ between $\mathrm{pH} 6.8$ and 8.0$)$ for these $\mathrm{Hbs}$ (Table 2). In the "stripped" condition, the $\mathrm{O}_{2}$-binding affinity

Table 2. Alkaline Bohr Effect $\left(\Delta \log P_{50} / \Delta \mathrm{pH}\right)$ of Hemoglobins from Human ( $\mathrm{Hb} \mathrm{A}$ and $\mathrm{Hb} \mathrm{A}_{2}$ ), Woolly Mammoth ( $\mathrm{rHb}$ WM), and Asian Elephant ( $\mathrm{rHb} \mathrm{AE}$ ) in the Presence and Absence of Inositol Hexaphosphate (IHP) ${ }^{a}$

\begin{tabular}{|c|c|c|c|c|c|}
\hline \multicolumn{2}{|c|}{ condition } & $\mathrm{Hb} \mathrm{A}$ & $\mathrm{Hb} \mathrm{A} \mathrm{A}_{2}$ & $\mathrm{rHb} \mathrm{WM}$ & $\mathrm{rHb} \mathrm{AE}$ \\
\hline MES buffer & $-\mathrm{IHP}$ & -0.53 & & -0.38 & -0.28 \\
\hline & +IHP & -0.79 & & -0.81 & -0.81 \\
\hline $\mathrm{NaPi}$ buffer & $-\mathrm{IHP}$ & -0.45 & -0.43 & -0.46 & -0.32 \\
\hline & +IHP & -0.67 & -0.71 & -0.72 & -0.47 \\
\hline
\end{tabular}

${ }^{a}$ Measurements were conducted at $37^{\circ} \mathrm{C}$ and over the $\mathrm{pH}$ range $7.0-$ 7.8 in $0.1 \mathrm{M}$ MES and sodium phosphate $(\mathrm{NaPi})$ buffers at a hemoglobin concentration of $100 \mu \mathrm{M}$.

of $\mathrm{Hb} \mathrm{A}$ shows a stronger Bohr effect $\left(\Delta \log P_{50} / \Delta \mathrm{pH}=\right.$ $-0.53)$, while $\mathrm{rHb} \mathrm{WM}$ and $\mathrm{rHb} \mathrm{AE}$ are characterized by lower Bohr coefficients $\left(\Delta \log P_{50} / \Delta \mathrm{pH}=-0.38\right.$ and -0.28 , respectively). However, upon the addition of IHP, Bohr coefficients of $\mathrm{rHb} \mathrm{WM}$ and $\mathrm{rHb} \mathrm{AE}$ reach their maximum $\left(\Delta \log P_{50} / \Delta \mathrm{pH}=-0.81\right)$, which is comparable to that of $\mathrm{Hb} \mathrm{A}$ $\left(\Delta \log P_{50} / \Delta \mathrm{pH}=-0.79\right)$. The Bohr effect of $\mathrm{rHb} \mathrm{WM}$ is slightly increased $(-0.46)$ in phosphate buffer and is further increased to about -0.70 upon the addition of IHP, very close to that of $\mathrm{Hb} \mathrm{A}$ and $\mathrm{A}_{2}$ under the same experimental conditions (Table 2). However, the Bohr effect of $\mathrm{rHb} \mathrm{AE}$ remains low $(-0.32)$ in phosphate buffer and only increase slightly $(-0.47)$ in the presence of IHP, a value still considerably lower than that of the other Hbs.

Effect of Temperature on Oxygen Affinity. The oxygen-binding affinity of $\mathrm{Hbs}$ is affected not only by allosteric effectors and $\mathrm{pH}$ but also by temperature. ${ }^{1,15}$ The temperature dependence of the oxygen affinity of $\mathrm{Hbs}$ has been measured at 37,29 , and $11{ }^{\circ} \mathrm{C}$, in the $\mathrm{pH}$ range of 5.5-8.5 in MES and phosphate buffers, respectively, and the results are summarized in Figure 5 and Supporting Information Figure 1S. As expected, $P_{50}$ values of $\mathrm{Hbs}$ are lower at $11^{\circ} \mathrm{C}$ than at $37{ }^{\circ} \mathrm{C}$, indicating that $\mathrm{O}_{2}$ binds tighter to $\mathrm{Hbs}$ at lower temperatures (Figure 5). In the absence of IHP, the $P_{50}$ values of these $\mathrm{Hbs}$ are in the same range, increasing from $\sim 3 \mathrm{mmHg}$ at $11^{\circ} \mathrm{C}$ to $\sim 16 \mathrm{mmHg}$ at $37^{\circ} \mathrm{C}$. However, the $P_{50}$ values of $\mathrm{rHb}$ WM exhibit a smaller increase for the same experimental temperature change. As illustrated in Figure $5 \mathrm{~A}, \mathrm{rHb} \mathrm{WM}$ has a lower $\Delta \log P_{50} / \Delta T$ value (0.023) in MES buffer, compared to $\mathrm{Hb} \mathrm{A}$ (0.034) and $\mathrm{rHb} \mathrm{AE}(0.028)$, where $\Delta T$ represents the difference between two temperatures (in ${ }^{\circ} \mathrm{C}$ ) and $\Delta \log P_{50}$ is the difference in $P_{50}(\mathrm{mmHg})$ at the two temperatures. In phosphate buffer, the $\Delta \log P_{50} / \Delta T$ values for these Hbs are all reduced, through that of $\mathrm{rHb} \mathrm{WM}(0.019)$ remains consistently lower than that of $\mathrm{Hb} \mathrm{A}(0.023)$ and $\mathrm{rHb} \mathrm{AE}(0.024)$. Upon the addition of IHP, all of the $P_{50}$ values at each experimental temperature increase, but the absolute values vary for each $\mathrm{Hb}$ because of their different response to IHP. In order to illustrate the temperature effect more clearly, the apparent heat of oxygenation, $\Delta H$, is calculated from the van't Hoff eq 1 on the basis of $\Delta \log P_{50}$ at the two different temperatures $\left(T_{1}\right.$ and $T_{2}$, in $\left.\mathrm{K}\right)$ :

$$
\begin{aligned}
& \Delta H\left(\mathrm{kcal} \mathrm{mol}^{-1} \mathrm{O}_{2}\right) \\
& \quad=-4.575\left(\mathrm{~T}_{1} \mathrm{~T}_{2} / \mathrm{T}_{2}-\mathrm{T}_{1}\right) \Delta \log P_{50} / 1000
\end{aligned}
$$

$\Delta H$ includes the heat of oxygen solvation $\left(-3 \mathrm{kcal} \mathrm{mol}^{-1}\right)$. The results of the exothermic oxygenation enthalpy $(\Delta H, \mathrm{~kJ}$ $\mathrm{mol}^{-1}$, where $1 \mathrm{cal}=4.184 \mathrm{~J}$ ) presented in Table 3 have been corrected for this value. It is noted that the $\Delta H$ values for the four $\mathrm{Hbs}$ are all $\mathrm{pH}$ dependent (Figure 6). For example, in phosphate buffer, the $\Delta H$ value for $\mathrm{rHb}$ WM changes from

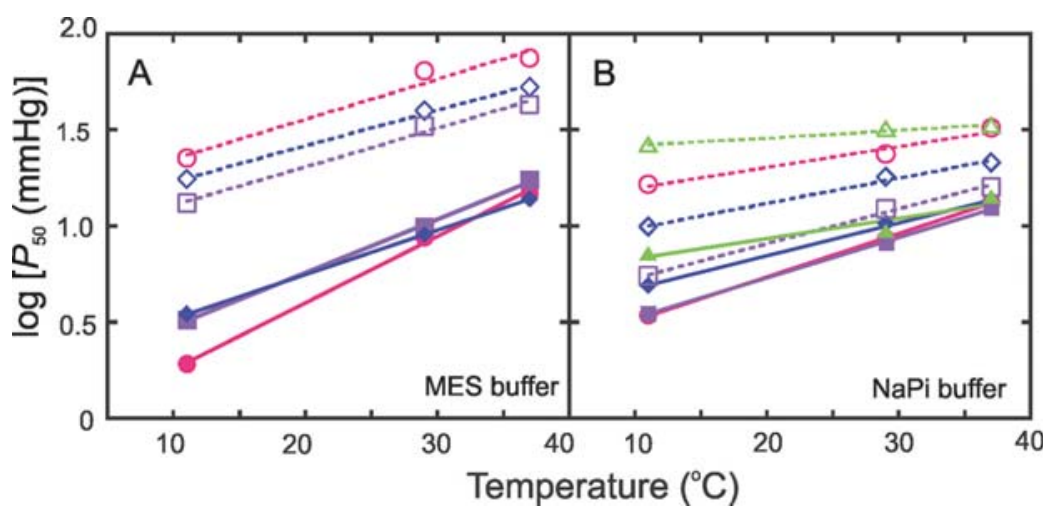

Figure 5. Comparison of temperature dependence of the oxygen-binding properties $\left[\log P_{50}(\mathrm{mmHg})\right]$ in the absence (filled) and presence (open) of $\mathrm{IHP}$ for $\mathrm{Hb} \mathrm{A}(\mathrm{O}, \mathrm{red}), \mathrm{Hb} \mathrm{A}_{2}\left(\triangle\right.$, green), $\mathrm{rHb} \mathrm{WM}\left(\diamond\right.$, blue), and $\mathrm{rHb} \mathrm{AE}\left(\square\right.$, magenta) measured at 11,29 , and $37^{\circ} \mathrm{C}:(\mathrm{A})$ at $\mathrm{pH} 7.0$ in $0.1 \mathrm{M}$ MES buffer; (B) at $\mathrm{pH} 7.4$ in $0.1 \mathrm{M}$ sodium phosphate ( $\mathrm{NaPi}$ ) buffer. 
Table 3. Apparent Enthalpy of Oxygenation $\left(\Delta H ; \mathrm{kJ} \mathrm{mol}^{-1}\right.$ $\mathrm{O}_{2}$ ) Values of Human ( $\mathrm{Hb} \mathrm{A}$ and $\left.\mathrm{Hb} \mathrm{A}_{2}\right)$, Woolly Mammoth (rHb WM), and Asian Elephant (rHb AE) Hemoglobin as a Function of $\mathrm{pH}^{a}$

\begin{tabular}{|c|c|c|c|c|c|}
\hline & & & $\Delta H(\mathrm{l}$ & $\left.\mathrm{nol}^{-1}\right)$ & \\
\hline buffer & $\mathrm{pH}$ & $\mathrm{Hb} \mathrm{A}$ & $\mathrm{Hb} \mathrm{A} A_{2}$ & $\begin{array}{l}\mathrm{rHb} \\
\mathrm{WM}\end{array}$ & $\mathrm{rHb} \mathrm{AE}$ \\
\hline MES & 5.80 & -42.0 & & -29.1 & -30.9 \\
\hline & 6.19 & -38.7 & & & \\
\hline & 6.53 & -40.8 & & -28.3 & -20.4 \\
\hline & 7.00 & -46.1 & & -25.9 & -30.6 \\
\hline & 7.40 & -42.7 & & & \\
\hline & 7.88 & -30.4 & & -26.7 & -31.7 \\
\hline MES + IHP & 5.80 & -19.9 & & -31.5 & -31.1 \\
\hline & 6.19 & -18.3 & & & \\
\hline & 6.53 & -19.4 & & -28.1 & -24.6 \\
\hline & 7.00 & -24.9 & & -19.1 & -22.2 \\
\hline & 7.40 & -27.1 & & & \\
\hline & 7.88 & -30.4 & & -14.6 & -17.5 \\
\hline $\mathrm{NaPi}$ & 5.79 & -41.4 & -44.5 & -41.0 & -42.5 \\
\hline & 6.23 & -39.2 & -42.7 & -36.7 & -41.6 \\
\hline & 6.57 & -33.0 & & & \\
\hline & 7.04 & -27.5 & -28.7 & -21.9 & -33.1 \\
\hline & 7.44 & -24.3 & -26.8 & -18.7 & -30.6 \\
\hline & 7.82 & -32.4 & -33.7 & -21.0 & -32.8 \\
\hline $\mathrm{NaPi}+\mathrm{IHP}$ & 5.80 & -29.5 & -35.9 & -38.8 & -40.9 \\
\hline & 6.26 & -27.1 & -32.2 & -32.2 & -38.2 \\
\hline & 6.84 & -28.3 & & -23.7 & -26.0 \\
\hline & 7.06 & & -31.3 & & -11.8 \\
\hline & 7.42 & -10.7 & -17.4 & -10.4 & -15.9 \\
\hline & 7.81 & -20.0 & -22.4 & -10.7 & -24.0 \\
\hline & 8.03 & -25.4 & & -28.4 & -40.9 \\
\hline "stripped"6 & & & & -35 & -35 \\
\hline$\underset{\mathrm{Cl}^{-6}}{\text { "stripped" + } 0.1 \mathrm{M}}$ & & -41.0 & & -27 & -31.5 \\
\hline $\begin{array}{l}0.1 \mathrm{M} \mathrm{Cl}^{-}+2.5 \mathrm{M} \\
\mathrm{BPG}^{6}\end{array}$ & & & & -19.3 & -28.1 \\
\hline
\end{tabular}

${ }^{a}$ Mean $\Delta H$ values of $\mathrm{Hbs}$ were calculated from $P_{50}$ values measured in the absence and presence of inositol hexaphosphate (IHP) in $0.1 \mathrm{M}$ MES and sodium phosphate $(\mathrm{NaPi})$ buffers at 11,29 , and $37^{\circ} \mathrm{C}$. Confidence limits of $\Delta H$ values are $\pm 15 \%$. Mean $\Delta H$ values previously determined for woolly mammoth and Asian elephant rHbs in $0.1 \mathrm{M}$ HEPES buffer at $\mathrm{pH} 7.0$ and 7.4 and over the temperature ranges 10 and $25{ }^{\circ} \mathrm{C}$ and 25 and $37^{\circ} \mathrm{C}^{6}$ are presented for comparison.
$-41.0 \mathrm{~kJ} \mathrm{~mol}^{-1}$ at $\mathrm{pH} 5.8$ to $-18.7 \mathrm{~kJ} \mathrm{~mol}^{-1}$ at $\mathrm{pH}$ 7.4. At $\mathrm{pH}$ 7.0 in the "stripped" condition, the $\Delta H$ values of $\mathrm{rHb} \mathrm{WM}$ and $\mathrm{rHb} \mathrm{AE}$ are -25.9 and $-30.6 \mathrm{~kJ} \mathrm{~mol}^{-1}$, respectively, much lower (in absolute terms) than that of human $\mathrm{Hb} \mathrm{A}(-46.1 \mathrm{~kJ}$ $\mathrm{mol}^{-1}$ ); i.e., $\mathrm{rHb} \mathrm{WM}$ and $\mathrm{rHb} \mathrm{AE}$ show a smaller temperature effect than $\mathrm{Hb} \mathrm{A}$. In phosphate buffer, the $\Delta H$ values of $\mathrm{rHb}$ $\mathrm{WM}$ are less negative than those of $\mathrm{rHb} \mathrm{AE}$, while the $\Delta H$ values of $\mathrm{Hb} \mathrm{A}$ and $\mathrm{Hb} \mathrm{A}_{2}$ are very similar over the range of experimental conditions. When IHP is present, the $\Delta H$ values of the four $\mathrm{Hbs}$ are all significantly decreased (in absolute terms), with that of $\mathrm{rHb} \mathrm{WM}$ remaining slightly lower than that of $\mathrm{rHb} \mathrm{AE}$. For all four Hbs, the lowest $\Delta H$ values (in absolute terms) are observed when both phosphate and IHP are present as functional modulators, suggesting an additive effect of phosphate and IHP to the $\Delta H$ value.

${ }^{1} \mathrm{H}$ NMR Spectra of Hemoglobins. ${ }^{1} \mathrm{H}$ NMR spectra were recorded for the $\mathrm{Hbs}$ in the deoxy and the $\mathrm{CO}$ forms in the absence and presence of IHP at 11,29 , and $37^{\circ} \mathrm{C}$. The exchangeable proton resonances of $\alpha 103 \mathrm{His}$ and $\alpha 122 \mathrm{His}$ of the four Hbs studied in the $\mathrm{CO}$ and deoxy forms are shown in Figure 7. In $\mathrm{Hb} \mathrm{A}$, the resonance at $12.2 \mathrm{ppm}$ has been assigned to the side chain $\mathrm{N} \varepsilon_{2} \mathrm{H}$ group of $\alpha 103 \mathrm{His}^{16-19}$ and the resonance at $12.9 \mathrm{ppm}$ has been assigned to the side chain $\mathrm{N} \varepsilon_{2} \mathrm{H}$ group of $\alpha 122 \mathrm{His}^{18}$ In the $\mathrm{CO}$ form of $\mathrm{Hbs}$ (Figure $7 \mathrm{~A})$, the peak at $12.2 \mathrm{ppm}(\alpha 103 \mathrm{His})$ is not present in the spectra of $\mathrm{rHb} \mathrm{AE}$ or $\mathrm{rHb} \mathrm{WM}$ but appears in the spectra for $\mathrm{Hb} \mathrm{A}$ and $\mathrm{A}_{2}$. Additionally, the peak at $12.9 \mathrm{ppm}(\alpha 122 \mathrm{His})$ in $\mathrm{Hb} \mathrm{A}$ is shifted downfield in the spectra of $\mathrm{rHb} \mathrm{AE}$ and $\mathrm{rHb}$ WM (which have $\alpha$ - and $\beta / \delta$-chains) and $\mathrm{Hb} \mathrm{A}_{2}$ (which has $\alpha$ - and $\delta$-chains). In the spectrum of deoxy-Hb A (Figure 7C), the resonance at $14 \mathrm{ppm}$ was assigned to the $\mathrm{H}$-bond between $\alpha 42$ Tyr and $\beta 99$ Asp and has been used as a T-state marker at the $\alpha_{1} \beta_{2}$ interface. $^{20}$ In the presence of IHP, the T-marker starts to appear in the spectra of the $\mathrm{CO}$ form of $\mathrm{Hb} \mathrm{A}$ and $\mathrm{Hb}$ $\mathrm{A}_{2}$ at a lower temperature $\left(11^{\circ} \mathrm{C}\right)$ but is not seen in the spectra of the $\mathrm{CO}$ form of $\mathrm{rHb} \mathrm{AE}$ and $\mathrm{rHb} \mathrm{WM}$ (Figure 7B). Significant differences are observed in the deoxy state of the Hbs (Figure 7C). As reported previously, the T-marker in deoxy- $\mathrm{Hb} \mathrm{A}_{2}$ is present at the same spectral position as that of deoxy-Hb A. ${ }^{13}$ These T-state markers shift $0.1-0.3$ ppm downfield in the spectra of $\mathrm{rHb} \mathrm{WM}$ and $\mathrm{rHb} \mathrm{AE}$, and the peak at $11.1 \mathrm{ppm}$ assigned to $\beta 37 \mathrm{Trp}$ also shifts $0.2 \mathrm{ppm}$ downfield at all temperatures, indicating a perturbation of the $\alpha_{1}(\beta / \delta)_{2}$ interface in $\mathrm{rHb} \mathrm{WM}$ and $\mathrm{rHb} \mathrm{AE}$ (Figure 7C).

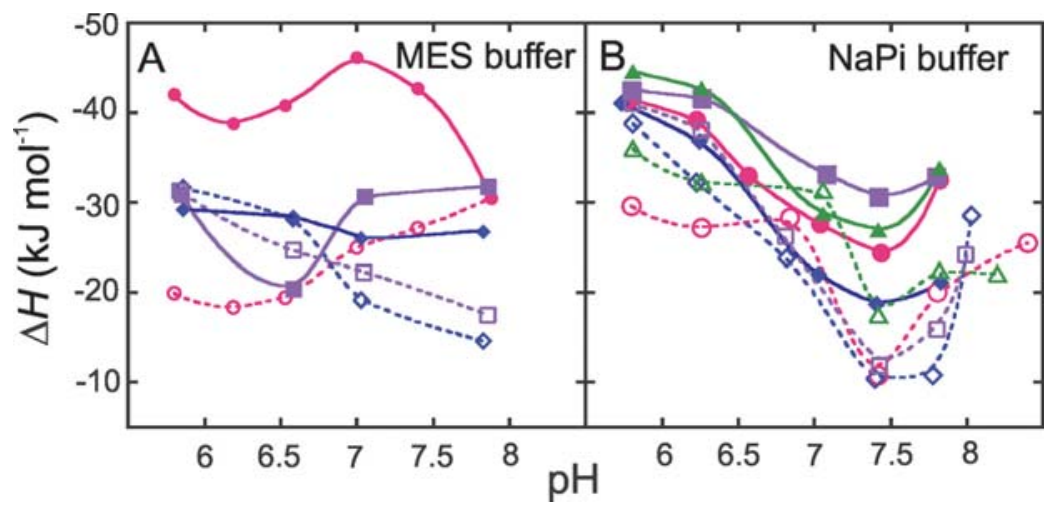

Figure 6. Apparent enthalpy of oxygenation $\left(\Delta H ; \mathrm{kJ} \mathrm{mol}^{-1} \mathrm{O}_{2}\right)$ values of $\mathrm{Hb} \mathrm{A}\left(\mathrm{O}\right.$, red), $\mathrm{Hb} \mathrm{A}_{2}(\triangle$, green), $\mathrm{rHb} \mathrm{WM}(\diamond$, blue), and $\mathrm{rHb} \mathrm{AE}(\square$, magenta), as a function of $\mathrm{pH}$. Mean $\Delta H$ values of $\mathrm{Hbs}$ were calculated from $P_{50}$ values measured at 11,29 , and $37^{\circ} \mathrm{C}(\mathrm{A})$ in $0.1 \mathrm{M}$ MES buffer and (B) in $0.1 \mathrm{M}$ sodium phosphate ( $\mathrm{NaPi}$ ) buffer and in the absence (filled) and presence (open) of IHP. Confidence limits of $\Delta H$ values are $\pm 15 \%$. 


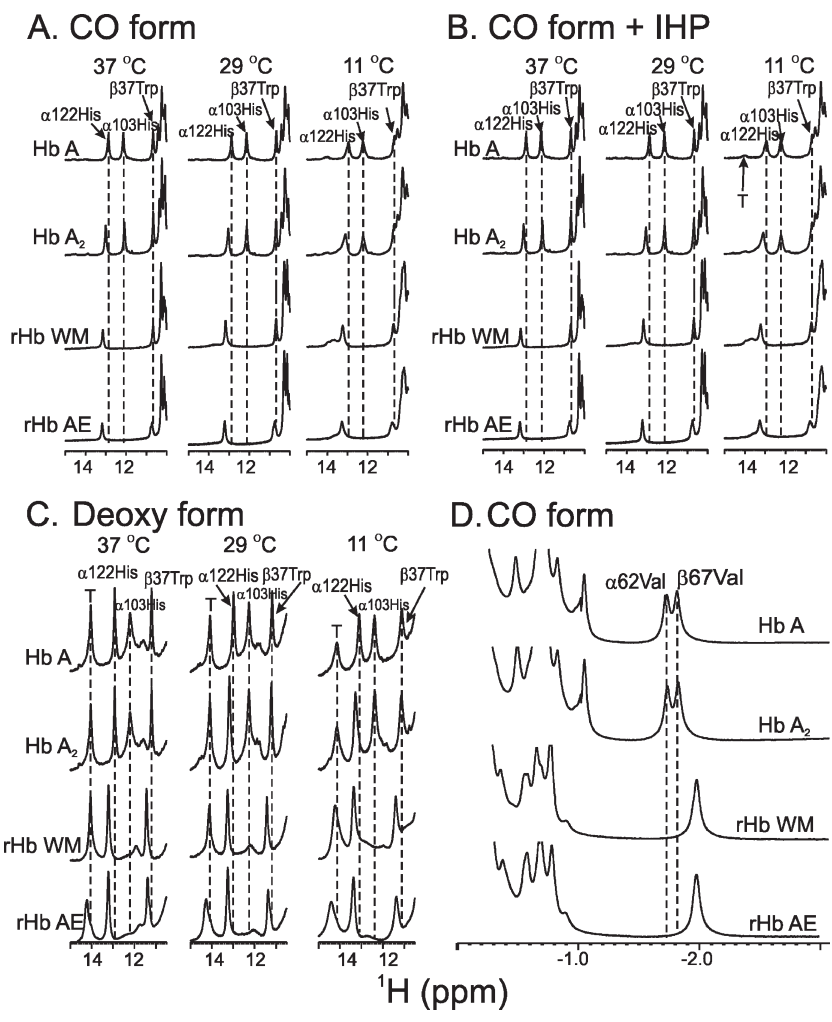

Figure 7. ${ }^{1} \mathrm{H}$ NMR spectra $(600 \mathrm{MHz})$ of $\mathrm{rHbs}$ in $95 \% \mathrm{H}_{2} \mathrm{O}, 5 \%$ $\mathrm{D}_{2} \mathrm{O}$, and $0.1 \mathrm{M}$ sodium phosphate buffer. Exchangeable proton resonances at $\mathrm{pH} 7.0$ and 11,29 , and $37{ }^{\circ} \mathrm{C}$, in the $\mathrm{CO}$ form in the absence (A) and presence (B) of IHP and in the deoxy form (C) are presented. (D) Ring-current-shifted resonances of the $\mathrm{CO}$ form of $\mathrm{Hbs}$ and $\mathrm{rHbs}$ at $\mathrm{pH} 7.0$ and $29^{\circ} \mathrm{C}$.

Ring-current-shifted resonances at -1.5 to $-2.0 \mathrm{ppm}$ (Figure 7D) provide information about the tertiary structure around the heme pocket. ${ }^{16}$ The resonances at -1.75 and $-1.82 \mathrm{ppm}$ have been assigned to the $\gamma_{2}-\mathrm{CH}_{3}$ group of E11Val of the $\alpha$ - and $\beta$-chains of $\mathrm{HbCO} \mathrm{A}$, respectively. ${ }^{21,22}$ For $\mathrm{rHb} \mathrm{WM}$ and $\mathrm{rHb} \mathrm{AE}$, the E11Val methyl resonances of both the $\alpha$ - and $\beta / \delta$-chains are shifted upfield to $-2.01 \mathrm{ppm}$, while the resonances of $\mathrm{Hb} \mathrm{A}_{2}$ are not affected.

\section{DISCUSSION}

Response to IHP. Mammals can be divided into two groups based on how the $\mathrm{O}_{2}$-binding affinities of their $\mathrm{Hbs}$ respond to allosteric effectors. The $\mathrm{O}_{2}$-binding affinities of $\mathrm{Hbs}$ from humans, pigs, dogs, and most primates are decreased in the presence of organic phosphate, whereas those from cats and ruminants are not sensitive to organic phosphate but exhibit significant effects in the presence of chloride ions. ${ }^{23-25}$ Our study has examined the properties of $\mathrm{rHb} \mathrm{WM}$ and $\mathrm{rHb} \mathrm{AE}$ with respect to their interactions with phosphate and IHP. Our results have confirmed that $\mathrm{rHb} \mathrm{WM}$ and $\mathrm{rHb} \mathrm{AE}$ belong to the group of mammalian $\mathrm{Hbs}$ that exhibit an intrinsically high oxygen affinity, which can be modulated by phosphate anions (i.e., phosphate and IHP). Comparisons between the $P_{50}$ values obtained in MES and sodium phosphate buffers show that the $\mathrm{O}_{2}$-binding affinities of $\mathrm{Hb} \mathrm{A}, \mathrm{rHb} \mathrm{WM}$, and $\mathrm{rHb} \mathrm{AE}$ significantly decrease in phosphate buffer and/or in the presence of IHP (Figure 2). However, the IHP effect is stronger in MES buffer than in phosphate buffer, suggesting that the allosteric effects of phosphate and IHP are not synergistic with respect to the $\mathrm{O}_{2}$ binding. Conversely, our results indicate that these two anions compete for the same binding sites. Thus, the changes of $P_{50}$ values of these $\mathrm{Hbs}$ upon the addition of IHP reach their maximum in MES buffer and cannot be increased further in phosphate buffer.

On the basis of our current studies, $\mathrm{rHb}$ WM exhibits a stronger response to allosteric effectors $\left(\mathrm{H}^{+}\right.$, phosphate, and $\mathrm{IHP}$ ), than $\mathrm{rHb} \mathrm{AE}$, despite possessing only three amino acid differences in their $\beta / \delta$-chain sequences. ${ }^{6}$ The functional properties of $\beta / \delta 101 \mathrm{Gln}$ in $\mathrm{rHb} \mathrm{WM}$ and $\beta / \delta 101 \mathrm{Glu}$ in $\mathrm{rHb}$ $\mathrm{AE}$ are of particular interest because this residue is located in the $\alpha_{1}(\beta / \delta)_{2}$ contact region. In liganded $\mathrm{Hb} \mathrm{A}, \beta 101 \mathrm{Glu}$ is in close contact with $\alpha 94$ residue, while in the deoxy- $\mathrm{Hb} \mathrm{A}$, it has contacts with both $\beta 94 \mathrm{Asp}$ and $\alpha 96 \mathrm{Val}$ residues. ${ }^{1,26}$ Thus, this residue is involved in the stabilization of both unliganded and liganded tetramers of $\mathrm{Hbs}$. Various mutations of $\mathrm{Hb} \mathrm{A}$ at $\beta 101 \mathrm{Glu}$ have been studied, but the role of this residue is still not clear. ${ }^{7}$ All mutant $\mathrm{Hbs}$ at this position have an elevated $\mathrm{O}_{2}$ affinity relative to $\mathrm{Hb} \mathrm{A}$, except for the mutant $\mathrm{Hb}$ Rush $(\beta 101 \mathrm{Glu} \rightarrow \mathrm{Gln})$, which is the only $\beta 101$ mutant having a higher sensitivity to chloride ion than $\mathrm{Hb} \mathrm{A}$. Consequently, despite possessing a high intrinsic $\mathrm{O}_{2}$ affinity (as in the other $\beta 101$ mutants), the $\mathrm{O}_{2}$ affinity of $\mathrm{Hb}$ Rush is decreased to a slightly lower value than that of $\mathrm{Hb} \mathrm{A}$ in the presence of $0.1 \mathrm{M}$ chloride. ${ }^{7}$ As suggested by Campbell et al., ${ }^{6}$ the $\beta / \delta 101 \mathrm{Glu} \rightarrow$ Gln substitution in $\mathrm{rHb} \mathrm{WM}$ might play the same role as in $\mathrm{Hb}$ A, which could allow the positive charge of $\beta / \delta 104 A$ rg to form an additional $\mathrm{Cl}^{-}$binding site within the $\alpha_{1}(\beta / \delta)_{2}$ interface of the deoxy-state molecule. This proposed additional chloridebinding site in $\mathrm{rHb} \mathrm{WM}$ might also be responsible for the increased allosteric effect caused by the addition of phosphate and IHP, as shown by the drastic decrease in $\mathrm{O}_{2}$ affinity of $\mathrm{rHb}$ $\mathrm{WM}$ in the presence of these allosteric effectors.

Bohr Effect. Oxygen-binding experiments show that both inorganic phosphate and IHP affect the functional behavior of $\mathrm{rHb} \mathrm{WM}$ and $\mathrm{rHb} \mathrm{AE}$, not limited only to the absolute value of the oxygen affinity, but also affecting the amplitude of the Bohr effect $\left(\Delta \log P_{50} / \Delta \mathrm{pH}\right)$. As shown in Table 2, in the "stripped" condition (i.e., MES buffer and in the absence of IHP), the $\Delta \log P_{50} / \Delta \mathrm{pH}$ values of $\mathrm{rHb} \mathrm{WM}$ and $\mathrm{rHb} \mathrm{AE}$ are lower (in absolute terms) than that of $\mathrm{Hb} \mathrm{A}$ between $\mathrm{pH} 6.8$ and 8.0. Bohr effects of the two elephantid $\mathrm{rHbs}$ are slightly influenced by the presence of inorganic phosphate but are markedly affected by the presence of IHP. For $\mathrm{Hb} \mathrm{A}$, it is known that there are a number of amino acid residues that contribute to the observed Bohr effects, including the $\mathrm{N}$-terminal residues ${ }^{27,28}$ and a large number of surface His residues. ${ }^{29-32}$ In $0.1 \mathrm{M}$ HEPES buffer with $0.1 \mathrm{M}$ chloride, $\beta 146 \mathrm{His}$ contributes the most to the alkaline Bohr effect (63\% at $\mathrm{pH} 7.4)$ among those surface histidyl residues, while $\beta 143 \mathrm{His}$ contributes the most to the acid Bohr effect (71\% at $\mathrm{pH} 5.1) .^{29-32}$ These two histidyl residues are also present in $\mathrm{rHb} \mathrm{WM}$ and $\mathrm{rHb} \mathrm{AE}$ and presumably also contribute to the Bohr effect of these proteins. It is noted that the number of histidyl residues in $\mathrm{rHb} \mathrm{WM}$ and $\mathrm{rHb} \mathrm{AE}$ is the same as in $\mathrm{Hb} \mathrm{A}$, but the locations of these residues are different (Table 1$). \beta 2 \mathrm{His}$ and $\beta 116 \mathrm{His}$ in $\mathrm{Hb} \mathrm{A}$, which exert moderate negative and moderate positive contributions, repectively, to the Bohr effect, ${ }^{31,32}$ have been replaced by $\beta / \delta 2$ Asn and $\beta / \delta 116 \mathrm{Arg}$ in $\mathrm{rHb} \mathrm{WM}$ and $\mathrm{rHb} \mathrm{AE}$. Thus, the contributions from these two histidyl residues to the Bohr effect are absent in $\mathrm{rHb} \mathrm{WM}$ and $\mathrm{rHb} \mathrm{AE}$. Consequently, 
the low Bohr effects observed for these two Hbs (Table 2) may arise from substitutions at $\beta / \delta 44(\mathrm{Ser} \rightarrow \mathrm{His})$ and $\beta / \delta 56(\mathrm{Gly} \rightarrow$ His), which presumably contribute negatively to the Bohr effect of these two proteins. Although $\mathrm{rHb} \mathrm{AE}$ has the identical histidyl residues as $\mathrm{rHb} \mathrm{WM}$, it exhibits a weaker Bohr effect in phosphate buffer, even in the presence of IHP, suggesting that the contributions from the histidyl residues might not account for all of the Bohr effect of these two rHbs. The lower Bohr effect of $\mathrm{rHb} \mathrm{AE}$ is consistent with its weaker response to phosphate and IHP relative to $\mathrm{rHb} \mathrm{WM}$ (Table 2).

Temperature Effects. The oxygenation of $\mathrm{Hb}$ is exothermic, with increasing the temperature lowering the $\mathrm{O}_{2}$ affinity directly by weakening the hydrogen bonds between $\mathrm{Hb}$ and $\mathrm{O}_{2}$. ${ }^{1,33,34}$ Arctic ruminants (e.g., musk ox and reindeer) are routinely subjected to extremely low environmental temperatures. Hence, to reduce the heat loss under these conditions, these animals exploit countercurrent heat exchangers in the extremities that allow them to maintain markedly lower tissue temperatures at these sites. ${ }^{3}$ Thus, a decrease in the temperature sensitivity of oxygen binding could be a functional strategy which allows unloading $\mathrm{O}_{2}$ to the cool peripheral tissues. This phenomenon has been observed in the previous studies for the $\mathrm{Hbs}$ of a number of subarctic and arctic mammals, including Eskimo dog, musk ox, and reindeer. ${ }^{5,35,36}$ The apparent heat of oxygenation, $\Delta H$, is used to evaluate the temperature effect on the $\mathrm{O}_{2}$ affinities of Hbs. On the basis of the $\Delta H$ values, the $H b s$ of various species can be broadly divided into two groups. The Hbs of the first group, including reindeer $\mathrm{Hb}$ and musk ox $\mathrm{Hb}$, have intrinsically low $\Delta H$ values even in the absence of allosteric effectors. ${ }^{5}$ The second group of $\mathrm{Hbs}$ can be further divided based on whether the large negative $\Delta H$ of these $\mathrm{Hbs}$ becomes less negative in the presence of 2,3-bisphosphoglyceric acid (2,3-BPG), such as pig $\mathrm{Hb}$ and fetal human $\mathrm{Hb}(\mathrm{Hb} \mathrm{F})$, or whether the $\Delta H$ is not very sensitive to the addition of 2,3-BPG, such as $\mathrm{Hb} \mathrm{A}{ }^{5}$ In the "stripped" condition, $\mathrm{rHb} \mathrm{WM}$ and $\mathrm{rHb} \mathrm{AE}$ have a less negative $\Delta H$ of oxygenation when compared with $\mathrm{Hb}$ A (Table 3 and Figure $6 \mathrm{~A}$ ). In phosphate buffer, the $\Delta H$ values of $\mathrm{rHb} \mathrm{WM}$ and $\mathrm{rHb} \mathrm{AE}$ decrease slightly and remain in the same range as in MES buffer, while that of $\mathrm{Hb} \mathrm{A}$ dramatically decrease (in absolute terms) compared to that in MES buffer (Table 3 and Figure 6B). Further comparisons between $\mathrm{rHb} \mathrm{WM}$ and $\mathrm{rHb} \mathrm{AE}$ show that although similar $\Delta H$ values are observed in MES buffer, $\mathrm{rHb}$ WM has much less negative $\Delta H$ values in phosphate buffer (Figure 6B), which can be attributed to the fact that the $\mathrm{O}_{2}$ affinity of $\mathrm{rHb} W M$ has a stronger response to phosphate, a weak allosteric effector. When IHP is present, the $\Delta H$ values of $H b s$ are greatly affected as the result of a change in the $P_{50}$ values. Differences between the $\Delta H$ values of the various $\mathrm{Hbs}$ remain but become smaller due to the strong allosteric effect of IHP (Figure 6). The less negative values of the $\Delta H$ values observed upon the presence of phosphate and/or IHP suggest that the apparent temperature effect is dependent on the ability of each of the $\mathrm{Hbs}$ to respond to the allosteric effectors. On the basis of the previous studies on the Hbs of various arctic animals, ${ }^{5}$ a potential structural explanation has been proposed, suggesting that the amino acid residues at $\beta 8$, $\beta 76$, and $\beta 77$ positions form an "additional" chloride-binding site (relative to $\mathrm{Hb} \mathrm{A}$ ), which is responsible for lowering $\Delta H$ of these proteins. ${ }^{37,38}$ Additionally, the mutation of $\beta 76 \mathrm{Ala} \rightarrow$ Lys might be responsible for the synergistic effect of 2,3-BPG and chloride on the $\mathrm{O}_{2}$ affinity of these $\mathrm{Hbs}^{38}$ In the $\mathrm{Hbs}$ of arctic animals, such as reindeer and ox, the amino acid residue at $\beta 76$ is Lys, and the $\Delta H$ values of these $H b$ s are less negative than that of horse $\mathrm{Hb}$, which has $\mathrm{Ala}$ at $\beta 76$. Both $\mathrm{rHb} \mathrm{WM}$ and $\mathrm{rHb}$ $\mathrm{AE}$ have $\beta / \delta 76 \mathrm{Lys}$, the same as in reindeer $\mathrm{Hb}$. Our previous study of $\mathrm{rHb} \mathrm{WM}$ suggests the E101Q substitution in $\mathrm{rHb} \mathrm{WM}$ creates an additional binding site for allosteric effectors, which contributes to the less negative $\Delta H$ of oxygenation relative to $\mathrm{rHb} \mathrm{AE}$, thus forming part of the physiological adaptation of woolly mammoth. ${ }^{6}$ The less negative $\Delta H$ values of $\mathrm{rHb} \mathrm{WM}$ observed in the present work confirm the lower temperature effect of $\mathrm{rHb} \mathrm{WM}$ compared to that of rHb AE. ${ }^{6}$

On the basis of our measurements, the $\Delta H$ values of $\mathrm{rHb}$ $\mathrm{WM}$ are in the same range as those of $\mathrm{Hbs}$ from other arctic animals obtained under similar experimental conditions. ${ }^{5}$ For example, in 0.1 M HEPES buffer with $0.1 \mathrm{M} \mathrm{NaCl}$ in the presence of 2,3-BPG, the $\Delta H$ of reindeer $\mathrm{Hb}$ is $-14.0 \mathrm{~kJ}$ $\mathrm{mol}^{-1}$, whereas the values calculated for $\mathrm{rHb} \mathrm{WM}$ are $-18.7 \mathrm{~kJ}$ $\mathrm{mol}^{-1}$ in $0.1 \mathrm{M}$ sodium phosphate buffer (current result) and $-19.3 \mathrm{~kJ} \mathrm{~mol}^{-1}$ in the presence of $\mathrm{Cl}^{-}$and $\mathrm{BPG}^{6}$ These low $\Delta H$ values of $\mathrm{rHb} \mathrm{WM}$ are consistent with life in the arctic environment since the $\mathrm{O}_{2}$ affinity of its $\mathrm{Hb}$ is less affected by low temperature, and therefore, it would be easier to unload $\mathrm{O}_{2}$ to the cool peripheral tissues. ${ }^{6}$ The $\Delta H$ value of $\mathrm{rHb} \mathrm{AE}$ is $-30.6 \mathrm{~kJ} \mathrm{~mol}^{-1}$ in phosphate buffer, which is more negative than that of $\mathrm{rHb}$ WM. However, it is reduced by the addition of IHP $\left(-15.9 \mathrm{~kJ} \mathrm{~mol}^{-1}\right)$, a value only slightly higher than that of $\mathrm{rHb}$ WM $\left(-10.4 \mathrm{~kJ} \mathrm{~mol}^{-1}\right)$. This suggests that a lower $\Delta H$ value observed from $\mathrm{rHb} \mathrm{AE}$ might be attributed to the stronger allosteric effect of IHP and that the reduction in the $\Delta H$ of $\mathrm{rHb} \mathrm{AE}$ is less pronounced in the presence of 2,3-BPG. ${ }^{6}$

In the stripped condition, the $\Delta H$ value for $\mathrm{Hb} A(-46.1 \mathrm{~kJ}$ $\mathrm{mol}^{-1}$ at $\mathrm{pH}$ 7.0) is more negative than that of $\mathrm{rHb} \mathrm{WM}$ $\left(-25.9 \mathrm{~kJ} \mathrm{~mol}^{-1}\right)$, and it is only slightly increased by $2,3-\mathrm{BPG}$ in the presence of chloride ions. ${ }^{5,39}$ In our study, when $\mathrm{Hbs}$ are saturated with IHP, the $\Delta H$ values for $\mathrm{Hb} \mathrm{A}$ are significantly increased to the same range as that of $\mathrm{rHb} \mathrm{WM}$ and $\mathrm{rHb} \mathrm{AE}$, suggesting that the $\mathrm{O}_{2}$ affinity and the $\Delta H$ value of $\mathrm{Hbs}$ are dependent on the property and the concentration of the allosteric effectors. It could also be the case for $\mathrm{Hbs}$ in the blood cells. For example, Asian and African elephant blood have slightly different functional properties, with the $\mathrm{O}_{2}$ affinity of Asian elephant blood being lower than that of African elephant due to an increased 2,3-BPG concentration in the red cells. $^{40,41}$

Structural Information from ${ }^{1} \mathrm{H}$ NMR Studies. ${ }^{1} \mathrm{H}$ NMR spectra of $\mathrm{Hbs}$ in $0.1 \mathrm{M}$ sodium phosphate buffer at $\mathrm{pH} 7.0$ were assessed at 11,29 , and $37^{\circ} \mathrm{C}$. One significant change shown in the ${ }^{1} \mathrm{H}$ NMR spectra is that the peak at 12.2 ppm disappears in the $\mathrm{CO}$ and deoxy forms of $\mathrm{rHb} \mathrm{WM}$ and $\mathrm{rHb} \mathrm{AE}$ (Figure 7). In $\mathrm{Hb} \mathrm{A}$, this resonance has been assigned to the side chain $\mathrm{N} \varepsilon_{2} \mathrm{H}$ group of $\alpha 103 \mathrm{His}$, which is hydrogen-bonded to $\beta 131 \mathrm{Gln} .{ }^{16-19}$ The resonance at $12.9 \mathrm{ppm}$ has been assigned to the side chain $\mathrm{N} \varepsilon_{2} \mathrm{H}$ group of $\alpha 122 \mathrm{His}$, ${ }^{18}$ which forms a water-mediated $\mathrm{H}$-bond with the side chain of $\beta 35$ Tyr. Both H-bonds are located at the $\alpha_{1} \beta_{1}$-subunit interface of $\mathrm{Hb}$ A. Our previous study of the mutant $\mathrm{rHb}(\beta 131 \mathrm{Gln} \rightarrow$ Glu) shows that the peak at $12.2 \mathrm{ppm}$ in the ${ }^{1} \mathrm{H}$ NMR spectrum disappears, suggesting that the H-bond between $\alpha 103 \mathrm{His}$ and $\beta 131 \mathrm{Gln}$ does not exist due to the replacement at the $\beta 131$ position. ${ }^{42}$ In $\mathrm{rHb} \mathrm{WM}$ and $\mathrm{rHb} \mathrm{AE}$, the amino acid residue of $\alpha 103 \mathrm{His}$ is the same as that in $\mathrm{Hb} \mathrm{A}$, but $\beta 131 \mathrm{Gln}$ existing in $\mathrm{Hb} \mathrm{A}$ is changed to $\beta / \delta 131 \mathrm{Glu}$ (Table 1 ). Thus, the 
disappearance of the resonance at $12.2 \mathrm{ppm}$ in the ${ }^{1} \mathrm{H}$ NMR spectra of $\mathrm{rHb} \mathrm{WM}$ and $\mathrm{rHb} \mathrm{AE}$ is likely to be caused by this mutation, as reported for the mutant $\mathrm{rHb}(\beta 131 \mathrm{Gln} \rightarrow \mathrm{Glu}){ }^{42}$ Our previous studies for $\mathrm{rHb}(\beta 131 \mathrm{Gln} \rightarrow \mathrm{Glu})$ also show a slight downfield shift of the $\alpha 122$ His resonance to $13.1 \mathrm{ppm}$, indicating that the perturbations caused by the replacement at $\beta 131$ are not just confined to the mutation site but also affect the environment of $\alpha 122 \mathrm{His}{ }^{42}$ This also could be true for the case of $\mathrm{rHb} \mathrm{WM}$ and $\mathrm{rHb} \mathrm{AE}$. Thus, the changes in ${ }^{1} \mathrm{H} \mathrm{NMR}$ spectra on the interface histidyl resonances of $\alpha 103 \mathrm{His}$ and $\alpha 122 \mathrm{His}$ could be attributed to the replacement of $\beta 131 \mathrm{Gln} \rightarrow$ Glu in $\mathrm{rHb} \mathrm{WM}$ and $\mathrm{rHb} \mathrm{AE}$. In the deoxy state of $\mathrm{rHb} \mathrm{WM}$ and $\mathrm{rHb} \mathrm{AE}$ (Figure $7 \mathrm{C}$ ), the $\mathrm{T}$-state markers located at $14.2 \mathrm{ppm}$ and the peak of $\beta 37 \mathrm{Trp}$ at $11.1 \mathrm{ppm}$ are shifted downfield, indicating a perturbation of the $\alpha_{1}(\beta / \delta)_{2}$ interface as well (Figure 7 ). Thus, in $\mathrm{rHb} \mathrm{AE}$ and $\mathrm{rHb} \mathrm{WM}$, both $\alpha_{1}(\beta / \delta)_{1}$ and $\alpha_{1}(\beta / \delta)_{2}$ interfaces are perturbed in both the deoxy and $\mathrm{CO}$ forms in the absence and presence of IHP as compared to those of $\mathrm{Hb} \mathrm{A}$ and $\mathrm{Hb} \mathrm{A}_{2}$. From the previous functional studies of the mutant $\mathrm{rHb}(\beta 131 \mathrm{Gln} \rightarrow \mathrm{Glu})$, it was shown that this mutation has only a small impact on the oxygen affinity of the $\mathrm{Hb}$ molecule. ${ }^{42}$ Thus, although a significant change is observed in the ${ }^{1} \mathrm{H}$ NMR spectra, the replacement of $\beta 131 \mathrm{Gln} \rightarrow$ Glu might not have an important effect on the function of $\mathrm{rHb} \mathrm{WM}$ and $\mathrm{rHb} \mathrm{AE}$.

On the basis of the previous studies of $\mathrm{Hb} \mathrm{A}$, the nonexchangeable ring current-shifted proton resonances at -1.75 and $-1.82 \mathrm{ppm}$ have been assigned to the $\gamma_{2}-\mathrm{CH}_{3}$ group of the $\alpha 62 \mathrm{Val}$ and $\beta 67 \mathrm{Val}$ residues of $\mathrm{HbCO} \mathrm{A}$, respectively. ${ }^{15,20,21}$ These resonances provide information about the geometry/ environment of the heme pocket. The ring-current-shifted resonances for these two valyl residues are resolved in the $\mathrm{CO}$ form of $\mathrm{Hb} \mathrm{A}$ and $\mathrm{Hb} \mathrm{A}_{2}$, but both shift upfield to $-2.0 \mathrm{ppm}$ in the $\mathrm{CO}$ form of $\mathrm{rHb} \mathrm{WM}$ and $\mathrm{rHb} \mathrm{AE}$ (Figure 7D). These results suggest that the distal heme pockets of $\mathrm{rHb} \mathrm{WM}$ and $\mathrm{rHb} \mathrm{AE}$ are altered as compared to those of $\mathrm{Hb} \mathrm{A}$ and $\mathrm{Hb} \mathrm{A}_{2}$. Comparing the amino acid sequences of these Hbs, several replacements in $\mathrm{rHb} \mathrm{WM}$ and $\mathrm{rHb} \mathrm{AE}$ can be found near $\alpha 62 \mathrm{Val}$ and $\beta 67 \mathrm{Val}$, including $\alpha 63 \mathrm{Ala} \rightarrow \mathrm{Gly}, \alpha 64 \mathrm{Asp} \rightarrow \mathrm{Glu}$, $\beta 65 \mathrm{Lys} \rightarrow \mathrm{Glu}$, and $\beta 69 \mathrm{Gly} \rightarrow \mathrm{Th}$. Previous studies have indicated that the mutations in the heme pocket of $\mathrm{Hb} \mathrm{A}$ can change the $\mathrm{O}_{2}$ affinity by affecting the tertiary structure of the protein. ${ }^{34,43,44}$ Our NMR studies reported here provide direct evidence showing that the geometry/environment of the heme pockets of $\mathrm{rHb} \mathrm{WM}$ and $\mathrm{rHb} \mathrm{AE}$ is different with respect to those of human $\mathrm{Hbs}$ and that these changes may be related to the higher $\mathrm{O}_{2}$-binding affinity of these $\mathrm{Hbs}$.

Structural Information from $\mathrm{Hb} \mathrm{A}_{2} \cdot \mathrm{Hb} \mathrm{A}_{2}$ exhibits a remarkable structural similarity to $\mathrm{Hb} \mathrm{A}$. The $\alpha$-chains are the same in these two $\mathrm{Hbs}$, and there are only 10 amino acid substitutions in the $\delta$-chain of $\mathrm{Hb} \mathrm{A}_{2}$ compared to the $\beta$-chain of $\mathrm{Hb} \mathrm{A}$. On the basis of the ring-current-shifted resonances of E11Val, no significant change in the distal heme pocket was detected due to the $\delta$-chain replacement (Figure 7D). In the ${ }^{1} \mathrm{H}$ NMR spectra of $\mathrm{Hb} \mathrm{A}_{2}$, the resonance at $13.1 \mathrm{ppm}$ shows a slight downfield shift, similar to that of $\mathrm{rHb} \mathrm{WM}$ and $\mathrm{rHb} \mathrm{AE}$, while the resonance at $12.2 \mathrm{ppm}$ is unchanged, suggesting that the $\delta$-chain replacement in $\mathrm{Hb} \mathrm{A}_{2}$ conserves the $\alpha_{1} \delta_{2}$ interface, but only slightly perturbs the $\alpha_{1} \delta_{1}$ interface. ${ }^{13}$ The perturbation on the intradimer interface is shown more clearly in the ${ }^{1} \mathrm{H}$ NMR spectra of $\mathrm{rHb} \mathrm{WM}$ and $\mathrm{rHb} \mathrm{AE}$ due to the combination effect of the $\beta / \delta$-chain replacement and the mutation of $\beta / \delta 131 \mathrm{Gln} \rightarrow$ Glu.

Perutz and Raidt reported that $\mathrm{Hb} \mathrm{A}_{2}$ was more resistant to thermal denaturation than $\mathrm{Hb} \mathrm{A}{ }^{45}$ They suggested that two amino acid residues in the helices $\mathrm{G}(\delta 116 \mathrm{Arg})$ and $\mathrm{H}$ ( $\delta 126 \mathrm{Met})$ of $\mathrm{Hb} \mathrm{A}_{2}$ might be responsible for its higher thermal stability. It is speculated that $\delta 116 \mathrm{Arg}$ could make an extra hydrogen bond at the $\alpha_{1} \delta_{1}$ interface and that $\delta 126 \mathrm{Met}$ $(\mathrm{H} 4)$ could make intrasubunit nonpolar contacts with $\delta 11 \mathrm{Val}$ of helix A. ${ }^{45}$ However, recent X-ray crystal studies of $\mathrm{Hb} \mathrm{A}_{2}$ did not support these additional interactions, but nonpolar contacts formed between helices $\mathrm{A}$ and $\mathrm{H}$ were found, which presumably contribute to the higher thermal stability of $\mathrm{Hb}$ $\mathrm{A}_{2} \cdot{ }^{10,46}$ Notably, $\mathrm{rHb} \mathrm{WM}$ and $\mathrm{rHb} \mathrm{AE}$ also possess Arg at position 116 of their $\beta$-type chains (Table 1), which may similarly elevate the thermal stability of these two Hbs. The $\mathrm{X}$-ray structural studies also suggest that the higher $\mathrm{O}_{2}$-binding affinity of $\mathrm{Hb} \mathrm{A}_{2}$ may result from the slighter larger $\alpha_{1} \delta_{2}$ interface of $\mathrm{Hb} \mathrm{A}_{2}$ and an additional hydrogen bond at the $\alpha_{1} \delta_{2}$ (or $\alpha_{2} \delta_{1}$ ) interface between $\alpha 94 \mathrm{Asp}$ and $\delta 37 \mathrm{Trp}$ in Hb A $\mathrm{A}_{2}{ }^{10}$ This could also be true for $\mathrm{rHb} \mathrm{WM}$ and $\mathrm{rHb} \mathrm{AE}$.

\section{CONCLUSION}

It is important to understand how the oxygen transport of Hbs is controlled by the combined action of temperature and ligands. Our studies on $\mathrm{rHb} \mathrm{WM}$ and $\mathrm{rHb} \mathrm{AE}$ have confirmed that these two $\mathrm{Hbs}$ respond differently to changes in experimental conditions. In general, the $\mathrm{O}_{2}$ affinity of $\mathrm{rHb} \mathrm{WM}$ has a larger response to allosteric effectors and is less sensitive to temperature change than $\mathrm{rHb} \mathrm{AE}$. These features are related to its structure and appear to arise from at least two of the three mutations found on the $\beta / \delta$ chain of this extinct species. It should be noted that our biochemical-biophysical study is limited to only the $\mathrm{Hb}$ molecule. In red cells, the factors that affect the oxygen affinity are more complex. Thus, the negative influences, such as a decrease in oxygen unloading due to a lower temperature, may be compensated by the action of one or more other factors. For example, it has been shown that blood of African and Asian elephants possess slightly different functional properties, with the $\mathrm{O}_{2}$ affinity of Asian elephant blood being lower than that of African elephant blood due to an increased 2,3-BPG concentration in the red cells. ${ }^{40,41}$ It is possible that such subtle difference also existed in woolly mammoth blood. The distinct structural features of $\mathrm{rHb} \mathrm{WM}$ provide a part of the basis for woolly mammoth survival in the arctic environment. Further investigations are needed for applying these structural features to the design of a new generation of medically relevant $\mathrm{Hb}$-based oxygen carriers.

\section{ASSOCIATED CONTENT}

\section{S Supporting Information}

Table 1S showing the Hill coefficient $\left(n_{50}\right)$; Table $2 S$ and Figure $1 S$ showing the concentration and temperature dependence of the oxygen-binding properties $\left(P_{50}\right)$ of $\mathrm{Hbs}$ under various experimental conditions, respectively. This material is available free of charge via the Internet at http:// pubs.acs.org.

\section{AUTHOR INFORMATION}

\section{Corresponding Author}

*Phone: 412-268-3395. Fax: 412-268-7083. E-mail: chienho@ andrew.cmu.edu. 


\section{Funding}

This work is supported by a research grant from the National Institute of Health (R01GM084614).

\section{ACKNOWLEDGMENTS}

We thank Dr. E. Ann Pratt for helpful comments on our manuscript.

\section{ABBREVIATIONS}

$\mathrm{Hb} \mathrm{A}$, human normal adult hemoglobin, the $\alpha_{2} \beta_{2}$ tetramer; $\mathrm{Hb}$ $\mathrm{A}_{2}$, a minor component of human normal adult hemoglobin, the $\alpha_{2} \delta_{2}$ tetramer; $\mathrm{rHb}$, recombinant $\mathrm{Hb}$; $\mathrm{rHb} \mathrm{WM}$, recombinant woolly mammoth $\mathrm{Hb}$; $\mathrm{rHb} \mathrm{AE}$, recombinant Asian elephant $\mathrm{Hb}$; $\mathrm{HbCO}$, carbonmonoxyhemoglobin; deoxy$\mathrm{Hb}$, deoxyhemoglobin; met-Hb, methemoglobin; NMR, nuclear magnetic resonance; DSS, 2,2-dimethyl-2-silapentane5-sulfonate; MES, 2-(N-morpholino)ethanesulfonic acid; 2,3BPG, 2,3-bisphosphoglycerate; IHP, inositol hexaphosphate.

\section{REFERENCES}

(1) Dickerson, R. E., and Geis, I. (1983) Hemoglobin: Structure, Function, Evolution, and Pathology, Benjamin/Cummings, Menlo Park, CA.

(2) Weber, R. E., and Campbell, K. L. (2011) Temperature dependence of haemoglobin-oxygen affinity in heterothermic vertebrates: mechanisms and biological significance. Acta Physiol. 202, 549-562.

(3) Irving, L., and Krog, J. (1955) Temperature of skin in the arctic as a regulator of heat. J. Appl. Physiol. 7, 355-364.

(4) Clementi, M. E., Condo, S. G., Castagnola, M., and Giardina, B. (1994) Hemoglobin-function under extreme life conditions. Eur. J. Biochem. 223, 309-317.

(5) De Rosa, M. C., Castagnola, M., Bertonati, C., Galtieri, A., and Giardina, B. (2004) From the Arctic to fetal life: physiological importance and structural basis of an 'additional' chloride-binding site in haemoglobin. Biochem. J. 380, 889-896.

(6) Campbell, K. L., Roberts, J. E. E., Watson, L. N., Stetefeld, J., Sloan, A. M., Signore, A. V., Howatt, J. W., Tame, J. R. H., Rohland, N., Shen, T. J., Austin, J. J., Hofreiter, M., Ho, C., Weber, R. E., and Cooper, A. (2010) Substitutions in woolly mammoth hemoglobin confer biochemical properties adaptive for cold tolerance. Nature Genet. 42, 536-540.

(7) Shih, D. T., Jones, R. T., Imai, K., and Tyuma, I. (1985) Involvement of Glu G3(101) $\beta$ in the function of hemoglobin. Comparative $\mathrm{O}_{2}$ equilibrium studies of human mutant hemoglobins. J. Biol. Chem. 260, 5919-5924.

(8) Opazo, J. C., Sloan, A. M., Campbell, K. L., and Storz, J. F. (2009) Origin and ascendancy of a chimeric fusion gene: the beta/ delta-globin gene of paenungulate mammals. Mol. Biol. Evol. 26, 14691478.

(9) Bunn, H. F., and Forget, B. G. (1986) Hemoglobin: Molecular, Genetic and Clinical Aspects, W.B. Saunders, Philadelphia, PA.

(10) Sen, U., Dasgupta, J. L., Choudhury, D., Datta, P., Chakrabarti, A., Chakrabarty, S. B., Chakrabarty, A., and Dattagupta, J. K. (2004) Crystal structures of $\mathrm{HbA}_{2}$ and $\mathrm{HbE}$ and modeling of hemoglobin $\delta_{4}$ : Interpretation of the thermal stability and the antisickling effect of $\mathrm{HbA}_{2}$ and identification of the ferrocyanide binding site in $\mathrm{Hb}$. Biochemistry 43, 12477-12488.

(11) Dexter, F., Kern, F. H., Hindman, B. J., and Greeley, W. J. (1997) The brain uses mostly dissolved oxygen during profoundly hypothermic cardiopulmonary bypass. Ann. Thorac. Surg. 63, 17251729.

(12) Shen, T. J., Ho, N. T., Simplaceanu, V., Zou, M., Green, B. N., Tam, M. F., and Ho, C. (1993) Production of unmodified human adult hemoglobin in Escherichia coli. Proc. Natl. Acad. Sci. U. S. A. 90, 81088112.

(13) Russu, I. M., Lin, A., Ferro-Dosch, S., and Ho, C. (1984) A proton nuclear magnetic-resonance investigation of human hemoglobin $A_{2}$ - Implications on the intermolecular contacts in Sickle hemoglobin fibers and on the Bohr effect of human normal adult hemoglobin. Biochim. Biophys. Acta 785, 123-131.

(14) Shen, T. J., Ho, N. T., Zou, M., Sun, D. P., Cottam, P. F., Simplaceanu, V., Tam, M. F., Bell, D. A., and Ho, C. (1997) Production of human normal adult and fetal hemoglobins in Escherichia coli. Protein Eng. 10, 1085-1097.

(15) Doyle, M. L., Gill, S. J., Decristofaro, R., Castagnola, M., and Dicera, E. (1989) Temperature-dependence and $\mathrm{pH}$-dependence of the oxygen-binding reaction of human-fetal hemoglobin. Biochem. J. 260, 617-619.

(16) Ho, C. (1992) Proton Nuclear-Magnetic-Resonance studies on hemoglobin - Cooperative interactions and partially ligated intermediates. Adv. Protein Chem., 153-312.

(17) Russu, I. M., Ho, N. T., and Ho, C. (1987) A proton nuclear Overhauser effect investigation of the subunit interfaces in human normal adult hemoglobin. Biochim. Biophys. Acta 914, 40-48.

(18) Simplaceanu, V., Lukin, J. A., Fang, T. Y., Zou, M., Ho, N. T., and Ho, C. (2000) Chain-selective isotopic labeling for NMR studies of large multimeric proteins: Application to hemoglobin. Biophys. J. 79, 1146-1154.

(19) Tsai, C. H., Shen, T. J., Ho, N. T., and Ho, C. (1999) Effects of substitutions of lysine and aspartic acid for asparagine at $\beta 108$ and of tryptophan for valine at $\alpha 96$ on the structural and functional properties of human normal adult hemoglobin: Roles of $\alpha_{1} \beta_{1}$ and $\alpha_{1} \beta_{2}$ subunit interfaces in the cooperative oxygenation process. Biochemistry 38, 8751-8761.

(20) Fung, L. W. M., and Ho, C. (1975) Proton nuclear magneticresonance study of quaternary structure of human hemoglobins in water. Biochemistry 14, 2526-2535.

(21) Dalvit, C., and Ho, C. (1985) Proton nuclear Overhauser effect investigation of the heme pockets in ligated hemoglobin - Conformational differences between oxy and carbonmonoxy forms. Biochemistry $24,3398-3407$.

(22) Lindstrom, T. R., Lehmann, H., Charache, S., Noren, I. B. E., and Ho, C. (1972) Nuclear magnetic-resonance studies of hemoglobins. 7. Tertiary structure around ligand binding-site in carbonmonoxyhemoglobin. Biochemistry 11, 1677-1681.

(23) Bunn, H. F. (1971) Differences in interaction of 2,3diphosphoglycerate with certain mammalian hemoglobins. Science 172, 1049-1050.

(24) Bunn, H. F. (1980) Regulation of hemoglobin-function in mammals. Am. Zool. 20, 199-211.

(25) Perutz, M. F., and Imai, K. (1980) Regulation of oxygen affinity of mammalian haemoglobins. J. Mol. Biol. 136, 183-191.

(26) Perutz, M. F. (1970) Stereochemistry of cooperative effects in haemoglobin. Nature 228, 726-733.

(27) Kilmartin, J. V., and Rossi-Bernardi, L. (1969) Inhibition of $\mathrm{CO}_{2}$ combination and reduction of the Bohr effect in haemoglobin chemically modified at its $\alpha$-amino groups. Nature 222, 1243-1246.

(28) Kilmartin, J. V., and Rossi-Bernardi, L. (1973) Interaction of hemoglobin with hydrogen ions, carbon dioxide, and organic phosphates. Physiol. Rev. 53, 836-890.

(29) Busch, M. R., Mace, J. E., Ho, N. T., and Ho, C. (1991) Roles of the $\beta 146$ histidyl residue in the molecular-basis of the Bohr effect of hemoglobin - a proton nuclear magnetic resonance study. Biochemistry 30, $1865-1877$.

(30) Sun, D. Z.P., Zou, M., Ho, N. T., and Ho, C. (1997) Contribution of surface histidyl residues in the $\alpha$-chain to the Bohr effect of human normal adult hemoglobin: Roles of global electrostatic effects. Biochemistry 36, 6663-6673. 
(31) Fang, T. Y., Zou, M., Simplaceanu, V., Ho, N. T., and Ho, C. (1999) Assessment of roles of surface histidyl residues in the molecular basis of the Bohr effect and of $\beta 143$ histidine in the binding of 2,3-bisphosphoglycerate in human normal adult hemoglobin. Biochemistry 38, 13423-13432.

(32) Lukin, J. A., and Ho, C. (2004) The structure-function relationship of hemoglobin in solution at atomic resolution. Chem. Rev. 104, 1219-1230.

(33) Weber, R. E., Campbell, K. L., Fago, A., Malte, H., and Jensen, F. B. (2010) ATP-induced temperature independence of hemoglobin$\mathrm{O}_{2}$ affinity in heterothermic billfish. J. Exp. Biol. 213, 1579-1585.

(34) Yuan, Y., Simplaceanu, V., Ho, N. T., and Ho, C. (2010) An investigation of the distal histidyl hydrogen bonds in oxyhemoglobin: Effects of temperature, $\mathrm{pH}$, and inositol hexaphosphate. Biochemistry 49, 10606-10615.

(35) Bårdgard, A. J., and Brix, O. (1997) Functional characterisation of Eskimo dog hemoglobin: II. The interplay of $\mathrm{HCO}_{3}{ }^{-}$and $\mathrm{Cl}^{-}$. Comp. Biochem. Physiol., Part A: Physiol. 117, 375-381.

(36) Bårdgard, A. J., Strand, I., Nuutinen, M., Jul, E., and Brix, O. (1997) Functional characterisation of Eskimo dog Hemoglobin: I. Interaction of $\mathrm{Cl}^{-}$and 2,3-DPG and its importance to oxygen unloading at low temperature. Comp. Biochem. Physiol, Part A: Physiol. 117, 367-373.

(37) Fronticelli, C. (1990) A possible new mechanism of oxygen affinity modulation in mammalian hemoglobins. Biophys. Chem. 37, $141-146$

(38) Fronticelli, C., Sanna, M. T., Perez-Alvarado, G. C., Karavitis, M., Lu, A.-L., and Brinigar, W. S. (1995) Allosteric modulation by tertiary structure in mammalian hemoglobins - Introduction of the functional characteristics of bovine hemoglobin into human hemoglobin by five amino acid substitutions. J. Biol. Chem. 270, 30588-30592.

(39) Giardina, B., Scatena, R., Clementi, M. E., Cerroni, L., Nuutinen, M., Brix, O., Sletten, S. N., Castagnola, M., and Condo, S. G. (1993) Physiological relevance of the overall delta H of oxygen binding to fetal human hemoglobin. J. Mol. Biol. 229, 512-516.

(40) Brown, I. R. F., and White, P. T. (1980) Elephant Blood Hematology and Chemistry. Comp. Biochem. Physiol., Part B: Biochem. Mol. Biol. 65, 1-12.

(41) Dhindsa, D. S., Sedgwick, C. J., and Metcalfe, J. (1972) Comparative studies of the respiratory functions of mammalian blood. 8. Asian elephant (Elephas maximus) and African elephant (Loxodonta africana africana). Respir. Physiol. 14, 332-342.

(42) Chang, C. K., Simplaceanu, V., and Ho, C. (2002) Effects of amino acid substitutions at $\beta 131$ on the structure and properties of hemoglobin: Evidence for communication between $\alpha_{1} \beta_{1}$ - and $\alpha_{1} \beta_{2}$ subunit interfaces. Biochemistry 41, 5644-5655.

(43) Maillett, D. H., Simplaceanu, V., Shen, T. J., Ho, N. T., Olson, J. S., and Ho, C. (2008) Interfacial and distal-heme pocket mutations exhibit additive effects on the structure and function of hemoglobin. Biochemistry 47, 10551-10563.

(44) Wiltrout, M.E., Giovannelli, J. L., Simplaceanu, V., Lukin, J. A., Ho, N. T., and Ho, C. (2005) A biophysical investigation of recombinant hemoglobins with aromatic B10 mutations in the distal heme pockets. Biochemistry 44, 7207-7217.

(45) Perutz, M. F., and Raidt, H. (1975) Stereochemical Basis of Heat-Stability in Bacterial Ferredoxins and in Hemoglobin- $\mathrm{A}_{2}$. Nature 255, 256-259.

(46) Dasgupta, J., Sen, U., Choudhury, D., Datta, P., Chakrabarti, A., Chakrabarty, S. B., Chakrabarty, A., and Dattagupta, J. K. (2003) Crystallization and preliminary X-ray structural studies of hemoglobin $\mathrm{A}_{2}$ and hemoglobin $\mathrm{E}$, isolated from the blood samples of $\beta$ thalassemic patients. Biochem. Biophys. Res. Commun. 303, 619-623. 